Review Paper

\title{
Halogen-free flame retardants for application in thermoplastics based on condensation polymers
}

\author{
Nicoleta Levința ${ }^{1,2} \cdot$ Zina Vuluga $^{2} \cdot$ Mircea Teodorescu $^{1} \cdot$ Mihai Cosmin Corobea ${ }^{2}$ (I)
}

C) Springer Nature Switzerland AG 2019

\begin{abstract}
Future materials in the field of thermoplastics require a lower impact on the environment. Actual thermoplastic materials also require "greener" additives for thermal and fire resistance profile. In this work, some of the recent solutions for halogen-free flame retardants were discussed in the context of viable routes with economical and industrial relevance. The fire retardant mechanism was discussed in order to imagine new solutions for future additives. Some of the main (inorganic, organic or hybrid) flame retardants can be used as common platform for the next classes of thermoplastic composites (synthetic, natural, or bio-based). The new generation of flame retardants (based on the emerging solutions) will have to surpass two major barriers: the cost effectiveness and the need for high concentration (which usually affects other properties).
\end{abstract}

Keywords Flame retardant - Thermoplastics · Condensation polymers · Polyamide · Polyesters · Polyurethanes . Emerging flame retardant

\begin{tabular}{|c|c|c|c|}
\hline \multicolumn{2}{|c|}{ Abbreviations } & \multirow[t]{2}{*}{ DiDopoMeO } & \multirow{2}{*}{$\begin{array}{l}\text { 6,60-(ethane-1,2-diylbis(azanediyl)) } \\
\text { bis(6H-dibenzo[c,e][1,2]oxaphosphinine } \\
\text { 6-oxide) }\end{array}$} \\
\hline ABPA & $\begin{array}{l}\text { Aluminium salt of diisobutylphosphinic } \\
\text { acid }\end{array}$ & & \\
\hline $\mathrm{AHP}$ & Aluminium hypophosphite & DOPO & 9,10-dihydro-9-oxa-10-phosphaphenan- \\
\hline AlPi & Aluminium phosphinate & & threne-10-oxide \\
\hline \multirow[t]{2}{*}{ APHP } & Aluminium & EG & Expandable graphite \\
\hline & polyhexamethylenephosphinate & FR & Flame retardant \\
\hline APP & Ammonium polyphosphate & FZrP & Functionalized zirconium phosphate \\
\hline AS & Ammonium sulfamate & GF & Glass fiber \\
\hline ATH & Aluminum trihydrate & HAPP & Hydroxyl-functionalized ammonium \\
\hline $\mathrm{CB}$ & Carbon black & & polyphosphate \\
\hline CNF & Carbon nanofibers & HNTs & Halloysite nanotubes \\
\hline CNTs & Carbon nanotubes & MCA & Melamine cyanurate \\
\hline DEP & DOPO-based diepoxide compound & MCAHP & Microencapsulated aluminum \\
\hline \multirow[t]{5}{*}{ DiDopoEDA } & 6-((6-oxidibenzo[c,e][1,2]oxaphosphinin- & & hypophosphite \\
\hline & 6-yl)methoxy)dibenzo[c,e][1,2]oxaphos- & $\mathrm{MgHP}$ & Magnesium hypophosphite \\
\hline & phinine 6-oxide) & $\mathrm{MH}$ & Magnesium trihydrate \\
\hline & & MMT & Montmorillonite \\
\hline & & MPP & Melamine polyphosphate \\
\hline
\end{tabular}

\footnotetext{
$\triangle$ Mihai Cosmin Corobea, mcorobea@yahoo.com | ${ }^{1}$ Department of Bioresources and Polymer Science, Faculty of Applied Chemistry and Materials Science, Polytechnic University of Bucharest, 1-7 Polizu Street, 011061 Bucharest, Romania. ${ }^{2}$ National Institute for Research and Development in Chemistry and Petrochemistry-ICECHIM, 060021 Bucharest, Romania.
} 


$\begin{array}{ll}\text { NC } & \text { Nanoclays } \\ \text { NPs } & \text { Nanoparticles } \\ \text { OMMT } & \text { Organo-modified montmorillonite } \\ \text { OZrP } & \text { Organo-modified zirconium phosphate } \\ \text { PA } & \text { Polyamide } \\ \text { PBS } & \text { Poly(butylene succinate) } \\ \text { PER } & \text { Pentaerythritol } \\ \text { PET } & \text { Polyethylene terephthalate } \\ \text { PLA } & \text { Polylactic acid } \\ \text { PP } & \text { Polypropylene } \\ \text { PUFs } & \text { Polyurethane foams } \\ \text { RPUF } & \text { Rigid polyurethane foams } \\ \text { ST } & \text { Corn starch } \\ \text { UPR } & \text { Unsaturated polyester resin } \\ \text { ZrP } & \text { Zirconium phosphate } \\ \text { COP } & \text { Carbon oxide production } \\ \text { EHC } & \text { Effective heat of combustion } \\ \text { HRC } & \text { Heat release capacity } \\ \text { HRR } & \text { Heat release rate } \\ \text { LOI } & \text { Limiting oxygen index } \\ \text { MLS } & \text { Mass loss rate } \\ \text { pHRR } & \text { Peak heat release rate } \\ \text { THR } & \text { Total heat release } \\ \text { Tp } & \text { Processing temperature } \\ \text { TSR } & \text { Total smoke release } \\ \text { TTI } & \text { Time to ignition } \\ & \end{array}$

\section{Introduction}

Flame retardant research for application in the field of polymer materials (either synthetic, bio-based or natural), is still an important direction nowadays [1]. The materials of the future tend to become lighter and "bio-based" as much as possible, in order to achieve the perfect renewability of resources [1-3]. These novel materials will involve more and more the organic matter [4-6]. The organic matter content will consist, as much as possible, in polymer or polymer like structures, of either bio-based or synthetic origin. In both cases the macromolecular structures derived from condensation reactions will play an active role. This role derives from two main directions: (1) natural polymer materials are mainly condensation polymers and (2) both synthetic and natural condensation polymers are more susceptible to biodegradation, being more attractive for enzymatic processes. In this context future applications of such materials will require more and more "reliable" solutions for their fire behaviour.

Amongst the two main classes of polymer materials, as far as their heating behaviour is concerned, namely thermoplastics and thermosets, the larger publishing interest expressed as number of papers released, was found for the first category (Fig. 1). The same major

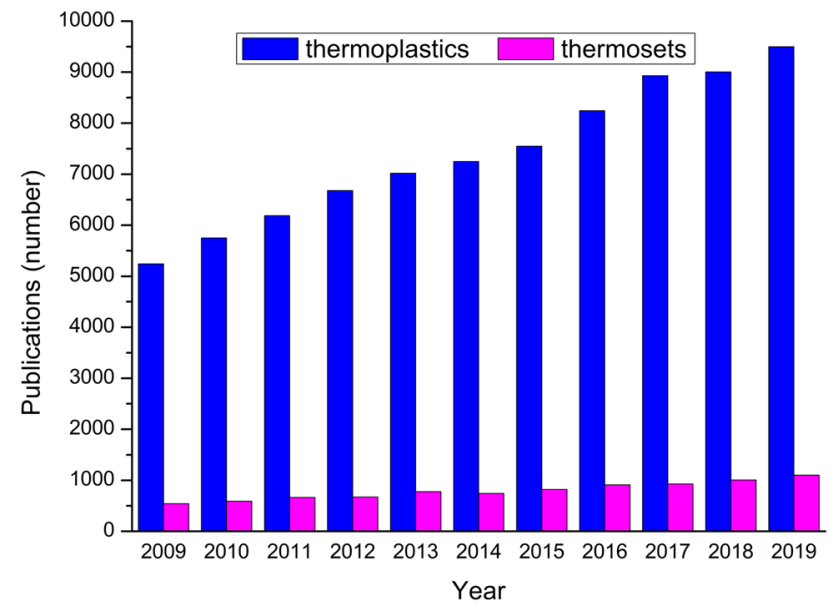

Fig. 1 Thermoplastics versus thermosets as number of publications (ISI indexed sources, reports or books) over the last 10 years (2019 estimated based on existing data and foreseen results)

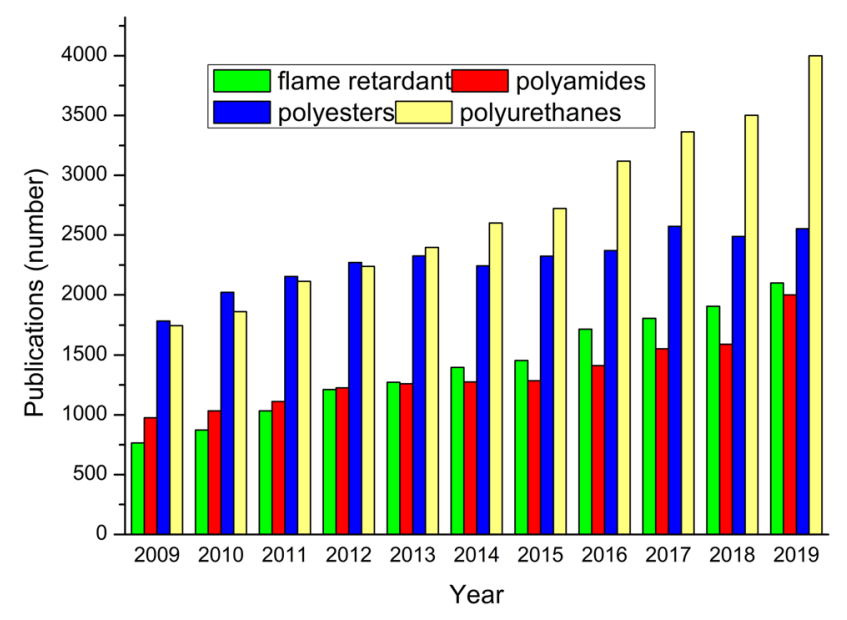

Fig. 2 Publication trends in sources (ISI indexed sources, reports or books) for flame retardant additives and the main thermoplastics based on condensation polymers (2019 estimated based on existing data and foreseen results)

interest was registered for the flame retardant topic, in connection with the three main classes of thermoplastics based on condensation polymers, i.e. polyamides, polyesters and polyurethanes (Fig. 2). The numbers dynamic was reflected by ISI indexed and impact factor publications, like articles, conferences, letters, data papers, proceedings papers, editorial materials, reviews and books, book reviews, chapters or other similar materials. This large interest reflects on one hand the large application potential and on the other hand the recycling ability [7]. Both directions require more intensive use and less ecological impact. In this context, the future materials are expected from now on, to be researched more and more within this region. Latest published research trends 
highlighted already the need for replacing several classical solutions.

There are several directions to improve the fire behaviour of polymer materials. A flame retardant (FR), for example, can be used as a comonomer, which, through a chemical reaction, will generate a FR polymer directly from the synthesis [8] or by the chemical modification of the prepolymer [9]. The FR additive can be also incorporated into the polymer matrix, through the melt processing method by generating physical interactions. This later route was proven to be a simple and efficient method that allows the processing of a wide range of polymers by either extrusion or injection moulding in order to achieve a higher fire performance $[10,11]$ at industrial level. However, some interesting attempts have also revealed the possibility of fire retardation by coating the polymeric surface with an intumescent layer $[12,13]$.

In order to develop an eligible additive formulation, three required agents must be put forth: the acid source, the carbonizing agent and the blowing agent. The acid donor leads to dehydration of the carbonizing agent that becomes a char, while the blowing agent is important because of the gaseous products it releases. Besides the basic characteristics of a flame retardant agent, an effective additive should also satisfy the following features: it should be inexpensive, affordable and moreover, compatible with the polymer it is loaded in, without drastically affecting other properties (for example, the mechanical properties). The main characteristics of halogen-free organic/inorganic flame retardants are illustrated in Fig. 3 [14].

Nowadays, the industrial market has a wide range of FRs including minerals and halogen-, phosphorus- and nitrogen-containing compounds. Although the halogenbased FRs have been the most used over time, now the main problem is restricting their use. These FRs involve some negative environmental impact. Halogenated FRs usually act in the gaseous phase, releasing toxic and corrosive gases, which along with the black smoke make them dangerous for the environment and human health.

\section{INORGANIC}

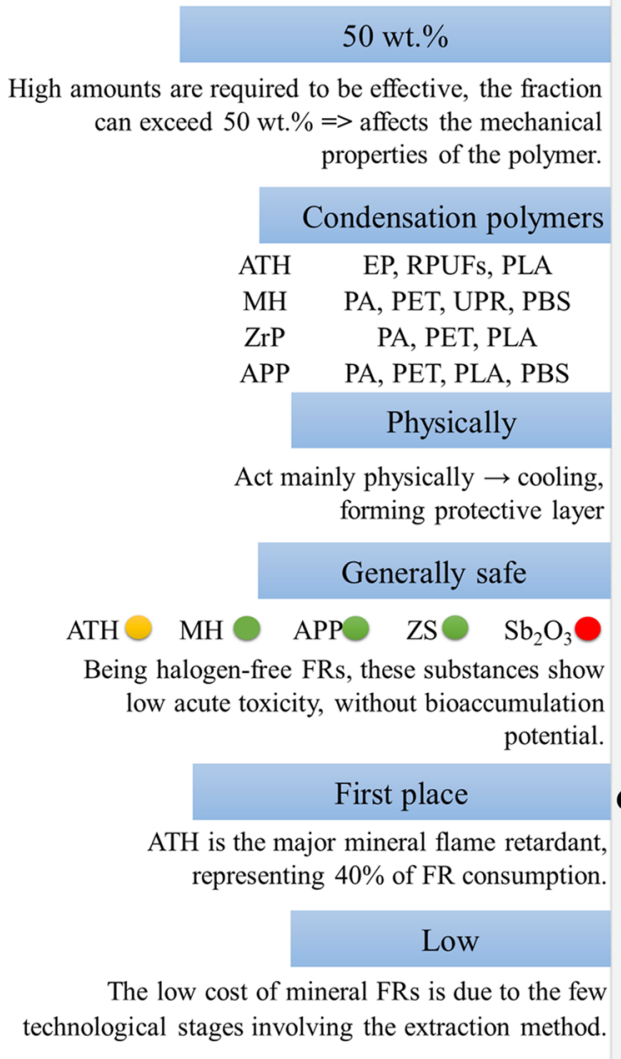

\section{Criteria}

Concentration

.

Polymer matrix

\section{ORGANIC}

$$
10-20 \text { wt. } \%
$$

Lower content can be used to achieve FR performance (10-20 wt.\%) offering a competitive price-performance ratio.

$\begin{array}{cc}\text { Condensation polymers } \\ \text { MCA } & \text { PA, PET, PUFs } \\ \text { DOPO } & \text { EP, PA } \\ \text { MPP } & \text { PA, PUFs, PLA, PBS }\end{array}$

Physically/chemically
$\begin{aligned} & \text { Act both physically and chemically - by } \\ & \text { reaction in the condensed or gas phase }\end{aligned}$

Environmental and Low level of concern health impact ${ }^{*}$

\section{MCA Triphyl-P DOPO}

The lack of halogen atoms in the chemical composition makes these compounds more environmentally friendly.

\section{Global consumption}

Third place

Organo-phosphorus are the third most widely used class of FR.

$\operatorname{Cost}^{* *}$

\section{High}

Organic synthesis is more complex, depending on volatile organic solvents that are costly.

DOPO Phosphinates Phosphonates

Fig. 3 The main characteristic of halogen-free inorganic/organic flame retardants ( ${ }^{*}$ with red-high impact, yellow—moderate, green-low impact; ** with red-high cost, yellow-moderate, green-low cost) 
Therefore, a tendency appeared for replacing these additives with halogen-free compounds (such as phosphorus/ nitrogen FR-Fig. 4). Plastic compositions contain a large number of additives. FR are next to other additives (like processing ones-i.e. plasticizers, or antioxidant agents) very probable to be release by plastic matrices in the environment causing severe impact on food, animals and human health. One major example is the release of plastic chemicals from packaging materials when used in the microwave field [15]. Bhunia et al. [16] highlighted in several examples how residual monomers from packaging polymers and additives are prone to be released in food when subjected to microwave heating. Recent development of bio-plastic [1] reduced the risk of such events by several ways: the use of greener additives; the absences of such additives in some particular cases; the major classes of natural polymers do not contain residual monomers and the degradation products of the natural polymers are not so toxic. Several bio-plastics compositions can withstand the conditions of the microwave. Another major example of environmental and health problem for existing plastic material is represented by microplastic [17] contamination - therefore halogen based FR are a great threat and greener FR additives are strong needed in this context [18]. The replacement of brominated FR is a major concern since the perspective of microplastic waste and pollution is a global problem with a wide localization [19-21]. Microplastic problem intrude little by little also the human body $[22,23]$, since several studies indicated the presence of microplastic (particles between 50 and 500 microns) in the human gut [24]. This phenomenon appears to occur more often for the people consuming seashell food, however also the packaging sector still represents another important source of microplastic. It seems that bioaccumulation could be the highest threat with two major ways of body entrance (ingestion-from diet sources and inhalation-from environmental sources) [25]. In this direction, a solution was developed by using bio-plastic materials [1] with biodegradable profile like starch or polysaccharide based. This class can be an alternative, since the degradation products are less likely to affect environment and health. These bio-plastic materials also request combinations with halogen-free FR [26]. The thermoplastic condensation polymers have found applications in a variety of fields: from packaging up to the automotive industry, increasing more and more the interaction with humans and environment. However, some applications started to ask for higher and higher safety requirements, or even led to a restriction due to their ignition capacity. In this context numerous studies to improve the fire performance of this polymer class have been carried out. There are several important areas that require the use of flame retardants, including electronics and electrical devices [27], the transportation industry (cars, trains, and airplanes) [28], furnishings, building and construction materials [29]. The increase of the transportation routes and volumes attracts also a higher fire risk, and therefore, the polymers used in building materials should be all flame retarded with halogenfree additives to reduce the release of smoke and delay the flame propagation for a few seconds. These seconds were proven critical in order to make a difference in the case of a conflagration or between life and death.

Polyamide (PA) is a well-known thermoplastic with applications in various areas such as textile, automotive, electrical and construction. These applications were made possible by employing flame retardant polyamide, which untreated, can easily burn into the atmosphere with a melt dripping behaviour. Aliphatic polyamides are less fire
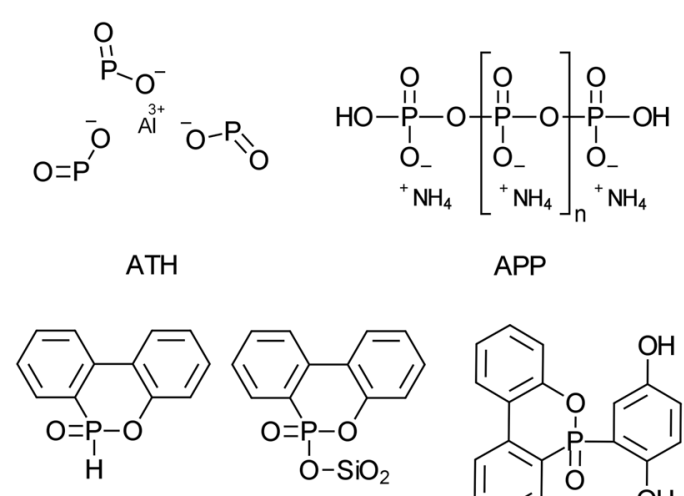

DOPO
APP

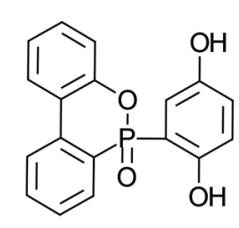

DOPO-HQ
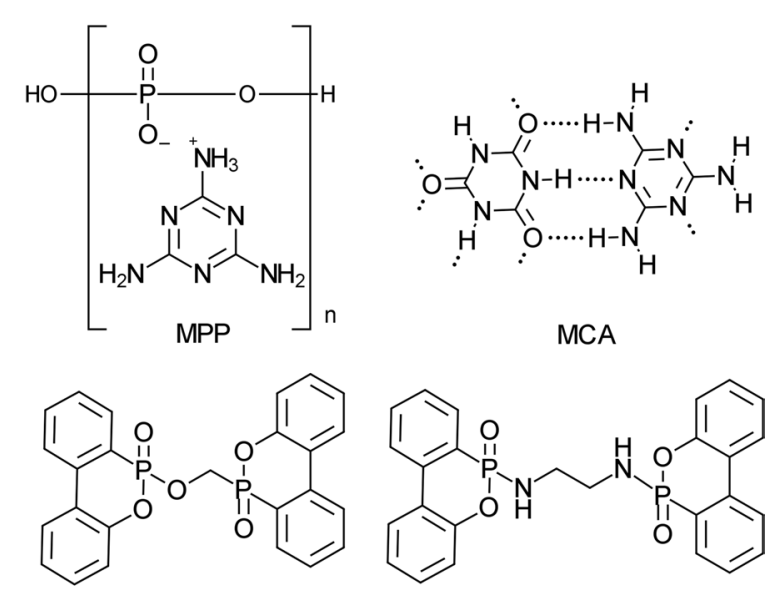

DiDopoMeO

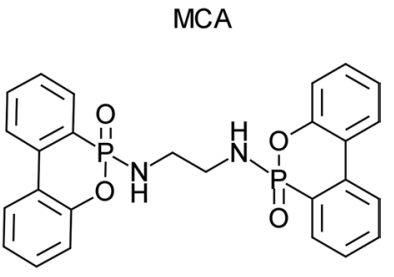

DiDopoEDA

Fig. 4 Chemical structure of some FRs 
resistant, with a LOI value around $21 \%$, while the aromatic polyamides have higher stability.

Polylactic acid (PLA) was often described as a biodegradable and biocompatible polymer obtained from renewable resource known for its medical performance or packaging applications. Although it was proven as a flammable polymer, like most thermoplastics, it has found several application in electrical and electronics fields [30]. This has become possible after improving the fire resistance of the PLA, which, being a biodegradable polymer, required a halogen-free flame retardant.

Another reason for using halogen free-flame retardants was the development of eco-friendly waterborne polyurethane [31] or solvent-free two-component polyurethane [32].

\section{Flame resistance mechanism and testing}

The flame retardant mechanism involves the chemical and physical interaction of the additive with the polymer matrix where it was loaded in. Under the action of heat, the high temperature of the polymer causes changes in its viscosity, leading to the formation of burning droplets. At the same time, fragmentation of macromolecular chains is followed by the appearance of compounds with low molecular weight. The combustion is maintained by the gases resulting from polymer degradation, which ignites itself in the presence of oxygen. The main role of the additive is to inhibit flame propagation, as burning of the resulting gases increases the level of heat, and the fire becomes uncontrolled. It is important to increase also the time between ignition and flame propagation, as there are seconds in the overall process which very often could save lives.
If, from chemical point of view, the additives inhibit radical formation, the physical action of FR could be described by three main effects. Firstly, the FR has the role of cooling the polymer structure. Examples in this regard are inorganic hydroxides, whose endothermic decomposition cools down the system [33]. On the other hand, the FR decomposition may result in the formation of a protective char layer at the polymer surface which represents a barrier between oxygen and decomposition gases, thus reducing the heat and mass transfer. Another mode of action is the dilution of the combustion gases by releasing inert gases/vapours such as carbon dioxide, ammonia and water during the decomposition of the FR.

There are several established methods to investigate the fire resistance of the polymeric materials. Scheme 1 illustrates some examples of the flammability standards applied to polymeric structures [34, 35].

Limiting oxygen index ( $L O I)$ was proven as the most common method to characterize the flammability of a material (e.g. plastic, textile, rubber) and represents a minimum oxygen concentration required to sustain combustion of a specimen for $3 \mathrm{~min}$ with a consumption of no more than $5 \mathrm{~cm}$ from the length of the sample [36].

The test is performed in a glass chamber where the sample was clamped in a vertical position and ignited at the top by a gas flame (propane gas). An oxygen/nitrogen mixture is led into the chamber and its composition is changed during the measurement to determine the minimum oxygen concentration. As the oxygen concentration in the air is $21 \%$, it is considered that the materials having $\mathrm{LOI}<21 \%$ will easily support burning in the air. The specimens exhibiting LOI values in the range of $21-28 \%$ are classified as slow-burning, while those with LOI higher than $28 \%$ are considered self-extinguishing.

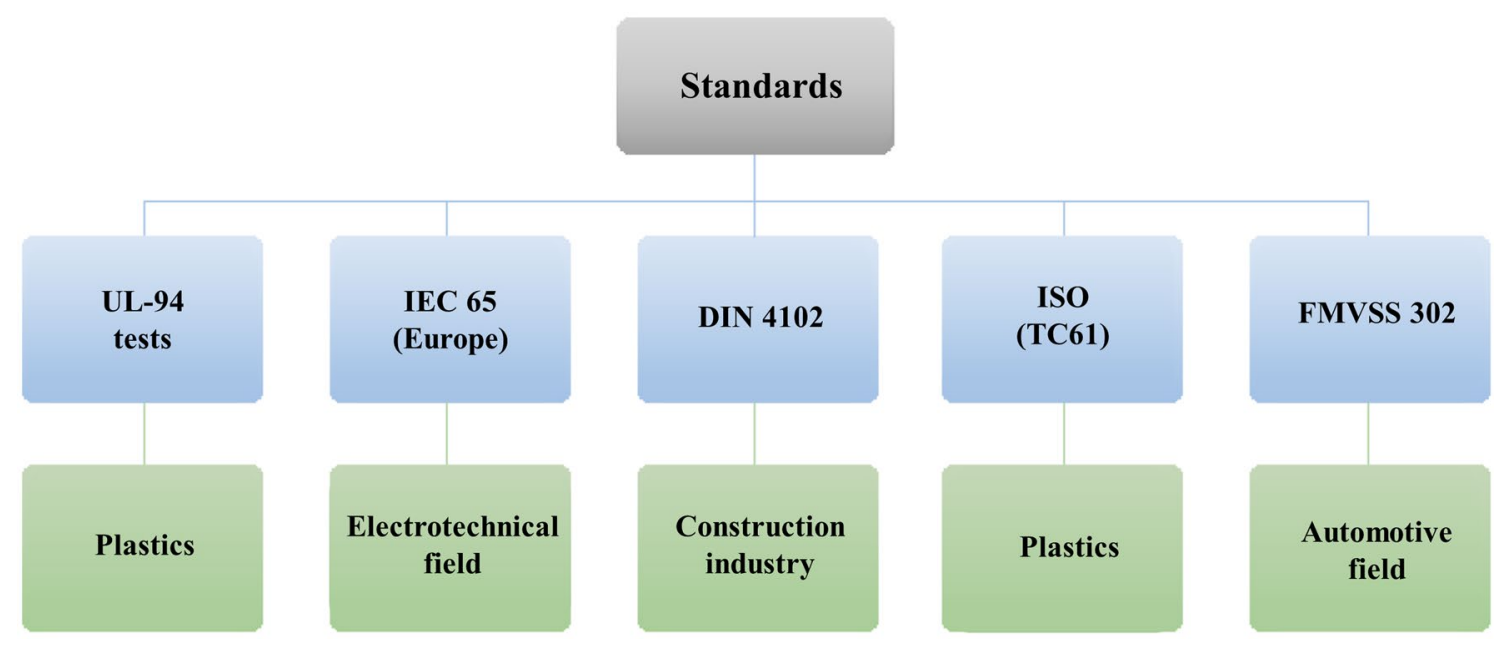

Scheme 1 Examples of the most used standards in polymer applications 
Based on the resulting values, this method offers the possibility of comparison between the fire resistance of different materials and the examination of the efficiency of the loaded FR. Table 1 summarizes several LOI values for some condensation polymers.

Although it cannot be anticipated under large-scale fire, the burning behaviour of the polymer material is usually estimated by UL-94 tests (Standard for Safety of Flammability of Plastic Materials for Parts in Devices and Appliances testing). This test was proven reliable for providing information about ignition, flame propagation and extinction. Usually the bar-shaped samples are used in vertical or horizontal position and depending on the burning time and dripping behaviour, the samples get a general classification: V0 (best), V1 (good), V2 (drips). Further development of the standard allowed a more precise assessment also for horizontal burn (HB-materials which are considered "self-extinguishing"), or surface burn (5VA burning stops within $60 \mathrm{~s}$, with no burn-through; 5VB burning stops within $60 \mathrm{~s}$, with a burn-through effect).

The cone calorimeter test evolved as a bench-scale method that allows the determination of oxygen consumption during combustion of the material. The analysis takes place in a cone calorimeter apparatus, where the specimen is exposed to a certain heat flux. A spark igniter initiates the combustion of the gases released from the heated sample. The resulting data are used to determine the heat release rate (HRR) - an important parameter in flammability study which is proportional with the oxygen consumption. Furthermore, this test is performed in order to achieve some thermal and smoke parameters such as time to ignition (TTI), mass loss rate (MLR), total smoke released (TSR), carbon oxide and carbon dioxide yields [42].

\section{Inorganic-based flame retardants}

Aluminium trihydrate (ATH) and magnesium hydroxide $(\mathrm{MH})$ are used in large quantities as halogen free-flame retardants because of their economic accessibility and non-corrosive and environment-friendly character. These

Table 1 LOI value examples for some of the most used condensation polymers

\begin{tabular}{lll}
\hline Polymer & LOl value (\%) & References \\
\hline PA 6 & 23.5 & {$[37]$} \\
PA 66 & 22.3 & {$[38]$} \\
PET & 22.5 & {$[39]$} \\
PU & 19.2 & {$[40]$} \\
PLA & 20.5 & {$[41]$} \\
\hline
\end{tabular}

inorganic hydroxides act as fire inhibitors by the following mechanisms:

- Endothermic decomposition, which means heat absorption and temperature reduction (cooling effect) in polymer matrix;

- The water vapour released from hydroxide decomposition dilutes the gases produced during burning, thus reducing the concentration of flame propagating radicals;

- The resultant metal oxide forms a protective layer at the surface which has the role of oxygen and heat insulating barrier.

ATH is used in various polymeric matrices, but a large amount is needed to get FR improvements. According to this, ATH was studied in combination with other additives in order to obtain a synergistic effect. Wang et al. synthesized a core-shell structure consisting of expandable graphite (EG) particles encapsulated with ATH for enhancing the fire behaviour of rigid polyurethane foams (RPUFs) [43]. The LOI test illustrated that the addition of $11.5 \mathrm{wt} \%$ FR increased the value from 21.5 to $29.6 \%$. As for cone calorimeter data, it was found that EG-ATH particles influence the TSR and carbon oxide production (COP) being suitable for flame retardancy of RPUFs.

Several studies reported the efficiency of the synergistic combination between ATH and APP [44-47]. Addition of APP and ATH into epoxy or unsaturated polyester resins reduces the value of combustion parameters, the samples becoming self-extinguishable at a concentration of $10 \mathrm{wt} \%$ ATH and $5 \mathrm{wt} \%$ APP [44]. For polyisocyanuratepolyurethane foams, cone calorimeter tests showed that the pHRR decreased, while the LOI values jumped from 21.2 to $28.0 \%$ at a filler content of $5 \mathrm{wt} \%$ ATH and $15 \mathrm{wt} \%$ APP [46].

The decomposition temperature of $\mathrm{MH}$ is higher by $100{ }^{\circ} \mathrm{C}$ than for $\mathrm{ATH}$, and that is why $\mathrm{MH}$ is used as FR in polypropylene (PP) [48], PA [49] and PET [50]. The endothermic degradation of $\mathrm{MH}$ results in the release of water that causes the hydrolysis of the polymer chains. The resulting compounds, mainly water, carbon dioxide and ammonia, have a beneficial effect in PA6 and PA66 fire retardancy, acting in both gaseous phase by dilution and condensed phase by forming a layer which prevents polyamide from further decomposition [51]. In addition, $\mathrm{MH}$ was studied as FR for PA6/PP composites [52]. It was found that $\mathrm{MH}$ protects the PA6/PP blends by forming a mineral crust during combustion. At a filler content greater than $30 \mathrm{wt} \%$, the samples showed favourable results in LOI and UL-94 analyses. However, the crystallinity and impact strength of PA6/PP composites were negatively affected. 
Yang et al. [53] investigated the efficiency of a novel FR system based on carbon microspheres coated (CMSs) by $\mathrm{MH}$ in improving fire behaviour of PET. It was shown that for PET loaded at only $1 \mathrm{wt} \%$ additive, a LOI of $27.5 \%$ and $\mathrm{V}-0$ classification, were reached. Fire performance of PET with $\mathrm{MH} / \mathrm{CMSs}$ was investigated by cone calorimeter test. The results suggested the decrease of the main characteristics: pHRR and MLS because of the cross-linking structure of char layer.

The necessity for a flame-retardant unsaturated polyester resin (UPR) was due to the fact that during combustion, this compound produces a lot of toxic gases, heat and smoke. Therefore, MH was an example of FR studied for delaying the propagation of fire after UPR ignition [54]. The evaluation of combustion performance illustrated that the FR properties of UPR were improved with increasing the additive concentration, the best fire behaviour being achieved at $55 \mathrm{wt} \% \mathrm{MH}$ content.

Zirconium phosphate $(\operatorname{ZrP})$ is an inorganic compound that presents interest due to its specific properties: biocompatibility $[55,56]$, thermal stability, ion-exchange ability [57]. These characteristics make possible the utilization of ZrP in catalysis [58], drug-delivery [56], photochemistry [59], anti-corrosion protection [60]. From morphological point of view, ZrP can be found in both amorphous and crystalline form. The most utilized method in order to synthesize the amorphous phase is by sol-gel method from which particles of different shapes are formed: spheres, cubes, globules and irregular shapes. The crystalline $\mathrm{ZrP}$ consists of a two-dimensional layered structure, as

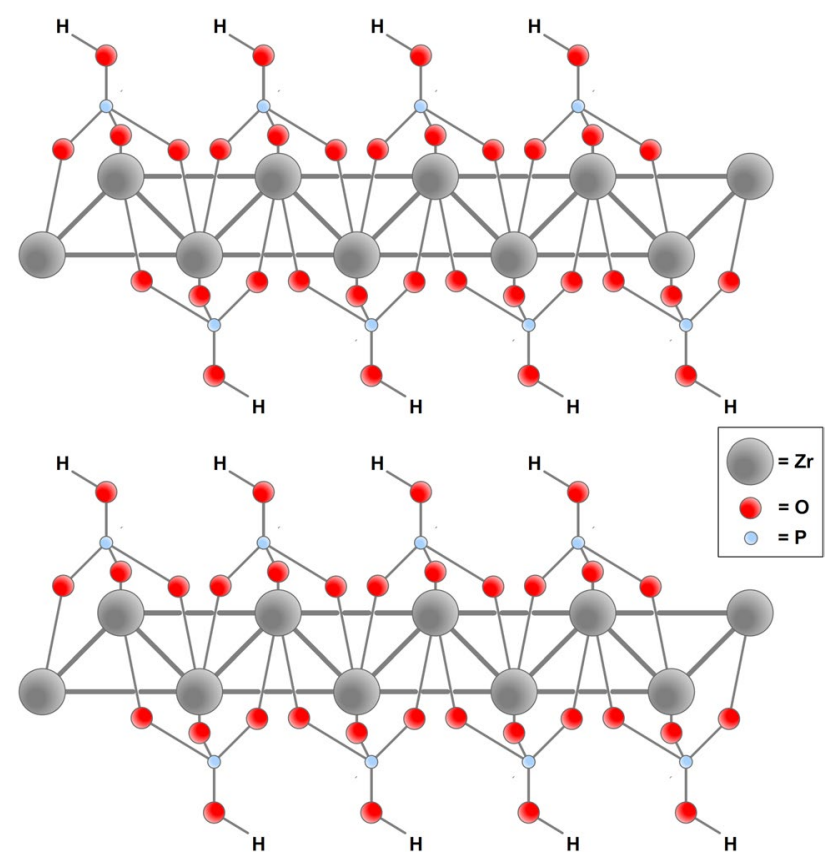

Fig. 5 Structure of a-ZrP illustrated in Fig. 5. Particularly for crystalline $\mathrm{ZrP}$ is the possibility to be exfoliated in a single layer and to achieve intercalation which allows in turn the modification of surfaces in order to obtain functional materials.

ZrP was proven as an effective flame retardant for various polymer matrices because of its thermal stability up to $800^{\circ} \mathrm{C}$. ZrP acts as a flame retardant by forming a ceramic layer on the surface, inhibiting the transfer of the heat and mass. In addition, $\mathrm{ZrP}$ is involved in the catalytic degradation of the polymer by proton attack on the macromolecular chains. Several studies investigated the fire performance of condensation polymers using ZrP as flame retardant. In this respect, PA6 and PET were flame retarded with $\mathrm{ZrP}$ by a melting process [61]. It was found that ZrP incorporated in PA6, reduces the HRR. In the case of flame-retarded PET, the flammability tests didn't show an improvement in the fire behaviour, therefore a second phosphorus-based additive was used. As a result of the synergistic effect, the samples were classified into $\mathrm{V}-0$ rating.

It was reported by Xiang et al. [62] that $a-Z r P$ had a good synergistic effect with ammonium sulfamate (AS) in PA6 matrix. The mechanical properties, thermal stability and combustion behaviour were investigated. A dosage of $3 \mathrm{wt} \% \mathrm{a}-\mathrm{ZrP}$ and $2 \mathrm{wt} \%$ AS was enough to obtain a LOI value of $38.7 \%$. As it can be seen, a larger amount of a-ZrP is used, because AS affects the mechanical properties of the polymer. All the specimens containing more than $1.5 \mathrm{wt} \%$ ZrP passed the UL-94 V-0 flammability rating.

Xiao et al. [63] synthesized a new flame retardant system made of melamine, cyanuric acid and a-ZrP. This additive was obtained by self-assembly of the three compounds and studied to reduce the flammability of PA6. When the concentration of a-ZrP-modified melamine cyanurate (MCA) was $10 \mathrm{wt} \%$, an improvement in the combustion properties of PA6 was achieved: reduction of the HRR and THR, V-0 rank in UL-94 test and anti-dripping effects. It was found that a content of $30 \mathrm{wt} \%$ MCA- $a-Z r P$ influences the crystallinity of PA6 inducing $Y$ phase formation.

Organo-modified or functionalized ZrP (OZrP or F-ZrP) were synthesized to improve fire behaviour of PLA systems $[64,65]$. It was reported that PLA composites loaded with a small amount of OZrP (1 wt\%) showed some improved properties: low HRR and THR and a LOI value increased from 19.0 to $35.5 \%$. In the case of F-ZrP, the initial decomposition temperature of the samples was slightly decreased, a V-0 rating was achieved and the LOI value was increased to $26.5 \%$. In both cases, it was found that the ZrP-based flame retardant contributes to the formation of a compact layer on the surface of char residue. In the same type of polyester, OZrP was used as a synergistic agent associated with polysulfonyldiphenylene phenyl 
phosphonate [66]. This mixture allowed the PLA fibres to exhibit a better fire performance. The results showed a $20 \%$ reduction in HRR, a maximum LOI of $29.3 \%$ and a UL-94V-0 classification.

Aluminium hypophosphite (AHP) is representative for phosphorus-containing flame retardants. This inorganic compound was examined in order to improve the thermal stability of condensation polymers.

After the addition of AHP filler, glass-fibre-reinforced PA6 showed better fire behaviour [67]. With increasing AHP content up to $25 \mathrm{wt} \%$, the LOI results showed higher value: from 22.5 to $30.1 \%$. It was found that AHP influences the combustion parameters of the composites. Therefore, pHRR, THR and TTI were significantly reduced. Regarding reinforced composites, preserving the mechanical properties after the additive loading was important. For this reason, $20 \mathrm{wt} \%$ AHP was the maximum concentration admitted.

Compared to magnesium hypophosphite (MgHP), AHP has a better effect on improving the fire behaviour of PA6 [68]. At an AHP content of $28 \%$, the samples passed the V-0 classification with an $\mathrm{LOI}$ value of $26.8 \%$, while at the same MgHP concentration the LOI reached only $23 \%$ and the $\mathrm{V}-2$ rating. It was established that AHP determines an early thermal decomposition of the composite which in turn exhibits better mechanical properties than PA6 loaded with MgHP.

Although AHP is a halogen free-flame retardant, it can release phosphine during its thermal or impact decomposition which can ignite itself in air. In order to prevent the spontaneous flammability of decomposed AHP, the microencapsulated technique was applied [69]. Through this method AHP was microencapsulated by MCA. The resultant MCA layer adsorbed on the surface of AHP presented the following functions:

- Increased fire safety;

- Synergistic effect with AHP making the composite a better FR;

- Resulted gases from MCA decomposition can dilute phosphines generated by AHP thus reducing the chances of a spontaneous explosion;

- Increased mechanical properties for the composite.

Microencapsulated aluminium hypophosphite (MCAHP) was studied as FR for PA6. The thermal degradation study of MCAHP demonstrated MCA efficiency in improving thermal stability of AHP by increasing the decomposition temperature of AHP from 330 to $350^{\circ} \mathrm{C}$. Samples supplemented with MCAHP showed an increase in LOI from 21 to $27.5 \%$ and a shift in the UL-94 classification from no rating to V-0. A good flame retardancy of PA6 has been proven by a significant decrease in HRR and THR combustion parameters.

Ammonium polyphosphate (APP) is a halogen-free flame retardant suitable for improving the fire performance of polyamides and polyurethane foam, as well as for polyolefins and epoxies. Moreover, it has a low cost and a good processability. The degree of polymerization influences the properties of APP and char formation of the composites that contain it [70]. APP starts to decompose at $240{ }^{\circ} \mathrm{C}$ releasing ammonia and phosphoric acid with no additional amount of smoke, which makes this additive eco-friendly.

Several studies demonstrated that APP combined with pentaerythritol (PER) enhance the fire properties of different polymeric formulations [71-73]. On the one hand, the addition of APP in PA6 matrix reduces the onset temperature of degradation by $100{ }^{\circ} \mathrm{C}$. This phenomenon is explained by the catalytic effect of the phosphoric acid resulted from the APP decomposition. On the other hand, PER favours the cross-linking process, increasing the char yield [74]. In bio-based PA1010, this intumescent formulation showed considerable changes in cone calorimeter analysis [75].Whereas the polymer matrix was obtained from natural sources, it was also investigated the partial replacement of PER with corn starch (ST). The results reveal that APP alone or in combination with PER or ST reduced pHRR up to $35 \%$, but at the same time, increased the TSR. It was concluded that the three additives led to the formation of a thermally stable residue. The presence of APP generated a thin and dense layer, and the combination with PER or ST results in the formation of an expanded char.

According to the main features of a FR, APP is an example of both acid source and blowing agent. $\mathrm{Li}$ et al. [76] investigated the anti-dripping effect of a PA66 fabric by using APP, PER and melamine as FRs. In this regard, APP acts as an acid source, PER is a char source, while melamine is a blowing agent. To investigate this synergistic effect, thermal, mechanical and combustion analyses were carried out. The PA66 fabric treated with all three FR achieved a LOI value of $27.9 \%$ with no dripping tendency. As for the mechanical properties, the untreated sample of PA66 showed a tensile strength of 190.1 MPa. By loading the polymeric matrix with APP, PER and melamine, $89 \%$ of this value was retained. It was found that this FR system improves the dripping resistance by increasing the intumescent char layer.

APP proved to be an effective additive for thermosetting materials like glass reinforced epoxy composites [77]. The necessity of flame-retarding this composite is due to the fact that glass fibre acts as a candlewick, generating an accelerated degradation of the polymer. At an APP content of $5 \mathrm{wt} \%$, the samples became 
self-extinguished, obtaining a V-0 rank in UL-94 tests. In terms of thermal and mechanical properties, APP does not induce significant changes due to its good distribution in the polymer matrix.

Several studies have focused on the development of APP-based systems to reduce the flammability of polyurethane foams. Zhang et al. [32] synthesized hydroxyl-functionalized APP (HAPP) via a cation exchange reaction in order to improve by chemical cross-linking the fire behaviour of a solvent-free two-component polyurethane. The results of LOI, UL-94 and cone calorimeter analyses suggested the effectiveness of the HAPP as FR, highlighted by the increased LOI value to $25.7 \%, \mathrm{~V}-1$ classification and decreased $\mathrm{pHRR}$, THR and TSP. The advantage of chemical incorporation of HAPP has been demonstrated by improving the tensile strength of the polymer matrix.

Microencapsulation is a commonly used method to enhance the interfacial interaction between FR and the polymer matrix. In this regard, Shen et al. [78] synthesized a core-shell structure of APP and 4,4'-oxydianiline-formaldehyde resin to be studied as FR in silanol-terminated polyurethane. This technique was proven as an effective strategy for improving the flame retardancy and compatibility of APP with bio-based polymers such as PLA and poly(butylene succinate) (PBS). Wang et al. [79] reported the influence of microencapsulated APP (MCAPP) on fire behaviour of PLA/starch composites. It was found that a concentration of $20 \mathrm{wt} \%$ of MCAPP/ME and $5 \mathrm{wt} \%$ of starch increased the LOI value to $38 \%$, samples obtaining a V-0 classification in UL-94 tests. The purpose of this study was also to limit the reaction between the acid source (MCAPP) and the carbonization agent (starch). In another research, APP was microencapsulated with thermally stable and hydrophobic ethyl cellulose to attain FR PBS composites [80]. According to cone calorimeter analysis, the pHRR and TTI were significantly reduced when MCAPP and CFA were added into the polymer matrix. It was found that the mechanical properties remained unchanged if the MCAPP concentration does not exceed $15 \mathrm{wt} \%$ and that of CFA- $5 \mathrm{wt} \%$.

\section{Organic-based flame retardants}

Melamine and its derivatives proved excellent flame retardant properties because of the different modes of action. MCA has been used as a halogen-free flame inhibitor for polyamides, polyesters and polyurethanes because of its processing temperature around $300^{\circ} \mathrm{C}$. At a higher temperature, the degradation of melamine and cyanuric acid begins with consequent formation of water, ammonia and carbon dioxide.
The structure of MCA consists in a 2D network of hydrogen bonds established between melamine and cyanuric acid, which increase the thermal stability and reduce the volatility of the MCA, making it a suitable flame retardant for polymer composites.

Several studies were focused on MCA incorporation in polyamides to limit their flammability. Lu et al. [81] prepared MCA/PA66 composites by melt-mixing technique and investigated their thermal and mechanical behaviour. A concentration of $10 \mathrm{wt} \%$ MCA was enough to achieve acceptable performance in flame retardancy, resulting a LOI of $33 \%$. The thermal stability of the samples decreased as a result of MCA incorporation into the PA matrix, while the crystallization temperature was increased. This was a consequence of the strong hydrogen bond interaction between the both components. As for the mechanical properties, the strength and the toughness of PA composites with $10 \%$ filler content were improved. In another study, partial replacement of MCA with modified-layered silicate (MLS) was attempted [82]. In this case, MCA was intercalated in layered silicates. Samples obtained by mixing and kneading PA66 with MLS and MCA in 93/3/4 ratio passed the UL-94 V-0 flammability rating and showed high mechanical properties. In the same way, the effect of the MCA mixture with carbon nanotubes (CNTs) and carbon black (CB) in PA6 was investigated by Šehić et al. [83]. A better reinforcing effect, thermal and combustion behaviour were obtained for PA6 composites fibres supplemented with MCA and CB.

MCA particles can present themselves under two dimensions: micro and nanometre-size. Geometries for micrometre-sized MCA particles can be sphere-like or rod-like, while nanometre-sized MCA particles can adopt a flake-like geometry. Tang et al. [84] investigated the influence of these morphologies on PA6 fire behaviour. The results of LOI and UL-94 tests suggested that nanometre-size flake-like MCA had a better effect on inhibiting PA6 flammability. Furthermore, it has been found that by reducing the size of the MCA particles, their decomposition temperature increases due to the strong hydrogen bonds they form with the polyamide.

There is the possibility to modify the internal hydrogen bond network formed between melamine and cyanuric acid. An example in this regard is the synthesis of MCA in the presence of nitrogenous bases such as: adenine, guanine, cytosine and uracil [85]. The resulting compounds were used to limit the flammability of PA6 composites. The PA6/cytosine-MCA sample displayed a LOI value of $30.7 \%$ and UL-94 V-0 rating, compared to PA6 examples containing other bases that showed a $\mathrm{V}-2$ rating. These results are explained by the fact that the cytosine-MCA particles are of smaller size, thus ensuring a better interaction with the polymer matrix. 


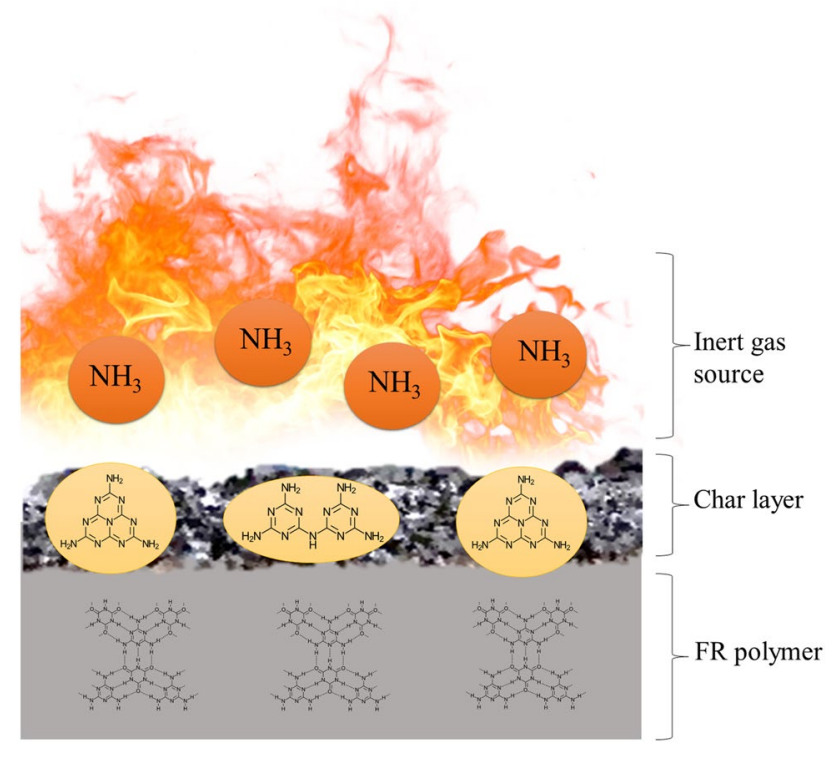

Fig. 6 Illustration of MCA action mode

MCA acts both forms: in the gaseous phase, being a source of inert gas as well as in the condensed phase by forming a fire barrier that protects the polymer during combustion (Fig. 6). There are several studies that have investigated the mechanisms of PA degradation [86-88]. On the one hand, PA 6 can be degraded by oxidative way, resulting caprolactam and cyclopentanone as the main products. On the other hand, the degradation is caused by weak bond-breakage on molecular chains which leads to incomplete depolymerization. In this case, oligomers with high-boiling point are obtained. It was shown, that MCA improves PA6 condensed phase because of the self-condensation of the resulting oligomers producing a stable cross-linking structure [89].

Yang et al. [10] tested the flame retardant mixture of MCA and AHP to improve the fire performance of PET/GF composites. The synergistic effect of MC with AHP was observed, which was argued by the fact that AHP acted as a flame inhibitor in the condensed phase, while MCA had a diluting effect in the gas-phase. As a result, the specimens showed a reduction of heat release capacity (HRC) by $47 \%$, an increase of LOI value by $31 \%$ and obtained a V-0 classification in UL-94 test. The combustion analysis showed that PET/GF composites formed a compact char that acted as an insulating barrier to oxygen and heat.

MCA proved to be effective also in reducing the flammability of polyurethane foams (PUFs). It was established that the samples displayed a better fire behaviour caused by the inclusion and increase of additives concentration [90]. Despite all of these, FR affects the mechanical properties and density of PUFs which is important for future applications of the polymer. Flexible PUFs are highly flammable, showing a LOI value of $18 \%$. Rao et al. [91] synthesized a novel melamine salt based on melamine and diphenylphosphinic acid that, incorporated in a flexible polyurethane matrix, acted as an efficient flame retardant. At a filler content of $30 \mathrm{phr}$, samples provided a LOI value of $25 \%$ and $\mathrm{V}-0$ rank in UL-94 vertical burning test.

Organophosphorus additives based on 9,10-dihydro9-oxa-10-phosphaphenanthrene-10-oxide (DOPO) were reported as suitable FR for reducing the flammability of epoxy resins [92-95] and polyurethane foams [96]. DOPObased FRs are used successfully to improve fire behaviour of polyamide [97] and polyester [98,99]. Compared to conventional FRs, a lower amount of DOPO derivatives is required to obtain good performance in polymer flame retardancy [100]. These compounds have FR effect mainly in the gas phase, releasing $P O$ radicals.

There are some studies on PA fire inhibition using DOPO derivatives. Bridged DOPO compounds were synthesized to be studied as FR for PA6: 6-((6-oxidibenzo[c,e][1,2] oxaphosphinin-6-yl)methoxy)dibenzo[c,e][1,2]oxaphosphinine 6-oxide) (DiDopoMeO) and 6,60-(ethane-1,2diylbis(azanediyl))bis(6H-dibenzo[c,e][1,2]oxaphosphinine 6-oxide) (DiDopoEDA) [101]. Flammability properties of these compounds were investigated compared to an usual P-content FR: aluminium diethylphosphinate (Exolit OP 1230). The results revealed that both DOPO derivatives improved LOI of $27.1 \%$ for neat PA6 to $31.7 \%$ for DiDopoEDA/PA6 composites, achieving a $\mathrm{V}-0$ rating in UL94tests. As well as conventional FRs, bridged DOPO derivatives determine the formation of an insulating layer on the surface. The presence of bubbles demonstrates that DOPO acts mainly in the gas phase.

As for GFPA6T, a novel bridged DOPO-derivative (PNDOPO) were synthesized [102]. The fire behaviour of these samples was analysed in comparison to GFPA6T blended with OP 1230. At 15 wt\% PN-DOPO content, the LOI was $28.9 \%$, much lower as compared to the value given by the OP1230 additive but was improved as compared to neat GFPA6T. Cone calorimetric analysis illustrated the influence of PN-DOPO on HRR, THR and average $\mathrm{CO}_{2}$ yield by decreasing their values. Thermal analysis showed that by adding of DOPO, the degradation temperature of the composite decreases due to the earlier decomposition of the additive.

$\mathrm{Li}$ et al. [103] studied the FR mechanism of DOPO- $\mathrm{SiO}_{2}$ and a phosphorus-nitrogen based additive incorporated in PA6 matrix. This system was chosen in order to act in both gaseous and condensed phase. It was found that this combination influences the flammability of the polymer by increasing the char stability. The LOI attained $31 \%$ and the char residue increased to $11.6 \%$ when $\mathrm{DOPO}-\mathrm{SiO}_{2}$ and 
OP1314 were used. In the PA66 copolymer, DOPO-SiO precursor decreased the pHRR by $33 \%$, while the effective heat of combustion (EHC) was reduced by $18 \%$ [104].

The chain extension with a DOPO-based diepoxide compound (DEP) is another method to enhance FR properties of PA6 [105]. The polymer loaded with 2 wt\% DEP and $10 \mathrm{wt} \%$ MCA passed the UL-94 test obtaining a V-0 classification, while the LOI jumped from 22.0 to $32.3 \%$. No dripping was observed.

By combining DOPO derivatives with conventional phosphorous-nitrogen additives, a highly efficient FR system is obtained. Hypophosphites produce radicals as $\mathrm{PO}$, $\mathrm{PO}_{2}, \mathrm{P}_{2} \mathrm{O}_{4}$. which have the role of $\mathrm{FR}$ inhibitors in the gaseous phase. Furthermore, the volatile gases are diluted by $\mathrm{N}_{2}, \mathrm{NH}_{3}$ and $\mathrm{H}_{2} \mathrm{O}$ released by the nitrogen-based FR. In condensed phase, the resulting char layer acts as an oxygen and heat barrier.

In order to obtain a global and comparative perspective between organic and inorganic flame retardants, previously discussed researches were structured in Tables 2 and 3.

\section{Other hybrid structures for flame retardants}

Phosphorus-based flame retardants, used in different forms such as: phosphates, phosphonates, phosphinates, are popular in this field because they can replace halogen-containing additives. Clariant Company patented

Table 2 Inorganic flame retardants for condensation polymers

\begin{tabular}{|c|c|c|c|c|c|}
\hline \multirow[t]{2}{*}{ Flame retardant } & \multirow[t]{2}{*}{ Polymer matrix } & \multicolumn{2}{|l|}{ Processing } & \multirow[t]{2}{*}{ FR properties } & \multirow[t]{2}{*}{ References } \\
\hline & & Method & Conditions & & \\
\hline MH (30 wt\%) & PA6/PP & $\begin{array}{l}\text { Extrusion (twin-screw } \\
\text { extruder-Brabender } \\
\text { Plasticorder) } \\
\text { Injection moulding }\end{array}$ & $\begin{array}{l}\mathrm{T}_{\mathrm{p}}=190^{\circ} \mathrm{C} \text {-feed sec- } \\
\text { tion } \\
\mathrm{T}_{\mathrm{p}}=240^{\circ} \mathrm{C} \text {-die head } \\
60 \mathrm{rpm} ; \\
\mathrm{T}_{\mathrm{p}}=200-240^{\circ} \mathrm{C}\end{array}$ & $\begin{array}{l}\text { V-1 rating in UL-94 } \\
\text { tests, No dripping } \\
\text { LOI }=27.2 \%\end{array}$ & {$[52]$} \\
\hline MH/CMSs (1 wt\%) & PET & $\begin{array}{l}\text { Melt blending } \\
\text { Twin-extruder (CET } \\
\text { 34-40D) } \\
\text { Injection moulding } \\
(\mathrm{JH600)}\end{array}$ & $\begin{array}{l}\mathrm{T}_{\mathrm{p}}=270,272,273,276, \\
287,280,282,285^{\circ} \mathrm{C} \\
15 \mathrm{rpm} ; \\
\mathrm{T}_{\mathrm{p}}=255,254,253,250^{\circ} \mathrm{C}\end{array}$ & $\begin{array}{l}\mathrm{LOI}=27.5 \% \\
\mathrm{~V}-0 \text { rating in UL- } 94 \text { tests }\end{array}$ & {$[53]$} \\
\hline APP (5 wt $\%)$ & Epoxy/glass fiber & $\begin{array}{l}\text { Ultrasonication (Hiels- } \\
\text { cher UP200S Ultrasoni- } \\
\text { cator) }\end{array}$ & $\begin{array}{l}24 \mathrm{kHz}, 50 \% \text { amplitude; } \\
\text { Vacuum oven: } 20 \text { min, } \\
\text { room temp.; } \\
\text { Curing: } 18 \mathrm{~h} \text {, room } \\
\text { temp.; } \\
\text { Post-curing: } 2 \mathrm{~h}, 80^{\circ} \mathrm{C}\end{array}$ & $\begin{array}{l}\text { Self-extinguishing } \\
\text { V-0 rank in UL-94 tests }\end{array}$ & {$[77]$} \\
\hline $\begin{array}{l}\text { APP/PER/ME (3:1:1) (38 } \\
\text { wt\%) }\end{array}$ & PA66 & $\begin{array}{l}\text { Fiber surface treat- } \\
\text { ment (immersion in } \\
\text { final solution, passed } \\
\text { through a padder with } \\
2 \text { dips/2nips) }\end{array}$ & Dried at $135^{\circ} \mathrm{C}, 4 \mathrm{~min}$ & $\begin{array}{l}\mathrm{LOI}=27.9 \% \\
\text { No dripping } \\
\downarrow \text { tensile strength }\end{array}$ & [76] \\
\hline $\begin{array}{l}\text { Hydroxyl-functionalized } \\
\text { APP }\end{array}$ & $\begin{array}{l}\text { Solvent-free two- } \\
\text { component polyu- } \\
\text { rethane }\end{array}$ & Chemical cross-linking & Curing: $100^{\circ} \mathrm{C}, 1 \mathrm{~h}$ & $\begin{array}{l}\downarrow \text { HRR by } 68.7 \% \\
\downarrow \text { THR by } 42.8 \% \\
\downarrow \text { TSP by } 9.3 \%\end{array}$ & {$[32]$} \\
\hline$a-Z r P(5 w t \%)$ & PA6 (Technyl 206C) & $\begin{array}{l}\text { Melt blending (Bra- } \\
\text { bender W50E) }\end{array}$ & $\begin{array}{l}\text { Polymer dried before in } \\
\text { a vacuum oven ( } 8 \mathrm{~h}, \\
\left.120^{\circ} \mathrm{C}\right) ; \\
\mathrm{T}_{\mathrm{p}}=240^{\circ} \mathrm{C}, 60 \mathrm{rpm}\end{array}$ & $\downarrow H R R$ & {$[61]$} \\
\hline $\begin{array}{l}\text { a-ZrP (3 wt\%)/Exolit } \\
\text { OP950 (12 wt } \%)\end{array}$ & PET & & $\begin{array}{l}\mathrm{T}_{\mathrm{p}}=255^{\circ} \mathrm{C}, 70 \mathrm{rpm}, \mathrm{mix}- \\
\text { ing time } 10 \mathrm{~min}\end{array}$ & V-0 rating in UL-94 tests & {$[61]$} \\
\hline $\begin{array}{l}\text { a-ZrP (3 wt } \%) / A S(2 \\
\text { wt } \%)\end{array}$ & PA6 (fiber grade) & $\begin{array}{l}\text { Composites Extrusion } \\
\text { (twin-screw extruder) } \\
\text { Fibers Melt spinning } \\
\text { machine }\end{array}$ & $\begin{array}{l}\mathrm{T}_{\mathrm{p}}=235^{\circ} \mathrm{C}, 100 \mathrm{rpm} ; \\
\mathrm{T}_{\mathrm{p}}=245-265^{\circ} \mathrm{C}, 800 \mathrm{~m} / \\
\quad \min \end{array}$ & $\begin{array}{l}\mathrm{LOI}=38.7 \% \\
\mathrm{~V}-0 \text { rating in UL-94 tests }\end{array}$ & {$[62]$} \\
\hline $\begin{array}{l}\text { Organo-modified ZrP } \\
\text { (1wt. \%)/IFR }\end{array}$ & PLA & $\begin{array}{l}\text { Extrusion (twin-screw } \\
\text { extruder) } \\
\text { Hot press }\end{array}$ & $\begin{array}{l}\mathrm{T}_{\mathrm{p}}=190^{\circ} \mathrm{C}, 50 \mathrm{rpm} ; \\
10 \mathrm{MPa}, 3 \mathrm{~min}, 210^{\circ} \mathrm{C}\end{array}$ & $\begin{array}{l}\mathrm{LOI}=35.5 \% \\
\downarrow \mathrm{HRR} \\
\downarrow \mathrm{THR}\end{array}$ & {$[64]$} \\
\hline
\end{tabular}


Table 3 Organic flame retardants for condensation polymers

\begin{tabular}{|c|c|c|c|c|c|}
\hline \multirow[t]{2}{*}{ Flame retardant } & \multirow[t]{2}{*}{ Polymer matrix } & \multicolumn{2}{|l|}{ Processing } & \multirow[t]{2}{*}{ FR Properties } & \multirow[t]{2}{*}{ References } \\
\hline & & Method & Conditions & & \\
\hline MCA (10 wt\%) & PA 66 (21ZLV) & $\begin{array}{l}\text { Melt-mixing technique } \\
\text { (SHR-10A high-speed } \\
\text { mixer) } \\
\text { Extrusion } \\
\text { Injection moulding }\end{array}$ & $\begin{array}{l}15 \text { min, room temp.; } \\
\mathrm{T}_{\mathrm{p}}=230^{\circ} \mathrm{C} \text {, dried at } \\
110^{\circ} \mathrm{C}, 3 \mathrm{~h} ; \\
\mathrm{T}_{\mathrm{p}}=260^{\circ} \mathrm{C}, 70 \mathrm{MPa} ; \\
\text { dried at } 23^{\circ} \mathrm{C}, 48 \mathrm{~h} \\
\text { before testing }\end{array}$ & $\begin{array}{l}\mathrm{LOI}=33 \% \\
\uparrow \mathrm{crystallization} \text { temp. } \\
\uparrow \text { strength } \\
\uparrow \text { toughness }\end{array}$ & {$[81]$} \\
\hline $\begin{array}{l}\text { MCA (4 wt\%)/mela- } \\
\text { mine-modified lay- } \\
\text { ered silicate ( } 3 \text { wt } \%)\end{array}$ & PA 66 (Technyl $\left.{ }^{\circledR} 216\right)$ & $\begin{array}{l}\text { Extrusion (twin-screw } \\
\text { extruder PCM30)- } \\
\text { one- and two-stage } \\
\text { kneading }\end{array}$ & $\mathrm{T}_{\mathrm{p}}=270^{\circ} \mathrm{C}$ & V-0 rating in UL-94 tests & {$[82]$} \\
\hline MCA/cytosine (9 wt\%) & PA 6 & $\begin{array}{l}\text { Melt blending (Bra- } \\
\text { bender) } \\
\text { Hot press }\end{array}$ & $\begin{array}{l}\mathrm{T}_{\mathrm{p}}=260^{\circ} \mathrm{C}, 50 \mathrm{rpm}, \\
\quad 6 \mathrm{~min} ; \\
\mathrm{T}_{\mathrm{p}}=250^{\circ} \mathrm{C}, 10 \mathrm{MPa}, \\
5 \mathrm{~min}\end{array}$ & $\begin{array}{l}\mathrm{LOI}=30.7 \% \\
\mathrm{~V}-0 \text { rank in UL-94 tests }\end{array}$ & {$[85]$} \\
\hline MCA/AHP (1:2) (10 wt\%) & PET/GF (30 wt\%) & $\begin{array}{l}\text { Melt-mixing technique } \\
\text { (Twin-roll mill XK-160) } \\
\text { Hot press }\end{array}$ & $\begin{array}{l}\mathrm{T}_{\mathrm{p}}=265^{\circ} \mathrm{C}, 100 \mathrm{rpm}, \\
10 \mathrm{~min} ; \\
\mathrm{T}_{\mathrm{p}}=265^{\circ} \mathrm{C}\end{array}$ & $\begin{array}{l}\downarrow \text { HRR by } 47 \% \\
\downarrow \text { THR by } 26 \% \\
\text { LOI }=31 \% \\
\text { V- } 0 \text { classification in } \\
\text { UL- } 94 \text { tests }\end{array}$ & {$[10]$} \\
\hline DiDopoMeO (17 wt\%) & PA 6 (Natur A26) & $\begin{array}{l}\text { Extrusion (HAAKE } \\
\text { Rheomex OS) } \\
\text { Injection moulding (Bat- } \\
\text { tenfeld Plus 350/75) }\end{array}$ & $\begin{array}{l}\mathrm{T}_{\mathrm{p}}=235-240^{\circ} \mathrm{C}, 85 \mathrm{rpm}, \\
2 \mathrm{~kg} / \mathrm{h} ; \\
\text { Dried at } 80,15 \mathrm{~h} ; \\
\mathrm{T}_{\mathrm{p}}=200-250^{\circ} \mathrm{C}\end{array}$ & $\begin{array}{l}\mathrm{LOI}=31.7 \% \\
\mathrm{~V}-0 \text { rank in UL-94 tests }\end{array}$ & [101] \\
\hline PN-DOPO (15 wt\%) & $\begin{array}{l}\text { GFPA6T (Zytel } \\
\text { HTN53G50HSLRHF } \\
\text { BK083) }\end{array}$ & $\begin{array}{l}\text { Extrusion (twin-screw } \\
\text { extruder) } \\
\text { Compression-molding }\end{array}$ & $\begin{array}{l}\mathrm{T}_{\mathrm{p}}=280,290,300,310, \\
320,315,310^{\circ} \mathrm{C} \\
150 \mathrm{rpm} ; \\
\mathrm{T}_{\mathrm{p}}=315,10 \mathrm{MPa}\end{array}$ & $\begin{array}{l}\mathrm{LOI}=28.9 \% \\
\mathrm{~V}-0 \text { rating in UL-94 tests } \\
\text { No dripping } \\
\downarrow \mathrm{HRR} \\
\downarrow \mathrm{THR}\end{array}$ & [102] \\
\hline DOPO-SiO 2 (10 wt\%) & PA 66/PA 6 (90:10 wt\%) & $\begin{array}{l}\text { Melt blending (twin- } \\
\text { screw extruder Leistriz } \\
\text { LSM model) }\end{array}$ & $\begin{array}{l}\mathrm{T}_{\mathrm{p}}=250^{\circ} \mathrm{C}, 150 \mathrm{rpm}, \\
3 \mathrm{~kg} / \mathrm{h}\end{array}$ & $\begin{array}{l}\downarrow \text { HRR by } 33 \% \\
\downarrow \text { THR by } 25 \% \\
\downarrow \text { EHC by } 18 \%\end{array}$ & [104] \\
\hline
\end{tabular}

FRs based on alkyl-substituted phosphinates, known as Exolit OP.

Aluminium salts of diethylphosphinate were reported as the most widespread example of organic phosphinate, identified as OP 1230, OP 1240, OP 1311, OP 1312. They were developed as general purpose FR systems, being studied for polyamides and polyurethane foam [106] fire retardancy.

Batistella et al. [107] investigated the flame retardancy of PA11 using Exolit OP 1311 as additive. Cone calorimeter analysis showed that the incorporation of $20 \mathrm{wt} \%$ FR additive in PA11 led to a significant decrease of pHRR (about $50 \%)$. The authors studied the partial replacement of the OP additive with another more available compound with comparable properties. In this case, kaolinite was chosen for its interaction with OP 1311 leading to the formation of new crystalline phases during combustion. Using OP $1311 /$ kaolinite (50:50) blends, the residue showed a higher phosphorus content, which demonstrates the capture of phosphorus compounds by kaolinite.
Additives may be chosen depending on the synergistic effect they have on the filler used. The usual fillers incorporated in polyamides are GF, nanoclays (NC) such as MMT and HNTs, CNTs and CNF.

About 5 wt $\%$ of NPs was enough to improve the flame retardancy of PA11 and reduce the amount of FR in the nanocomposites to $20 \%$ [108]. Lao et al. studied the flammability of PA-NC and PA-CNF with intumescent FR additive nanocomposites. In their study, three Exolit OP grades with different amounts of phosphorus content were used (OP 1311, OP 1312 and OP 1230). The decomposition temperature for $50 \%$ mass loss $\left(\mathrm{T}_{50 \%}\right)$ had a significant increase because of the synergistic effect of the two additives: phosphorus-based FR and nanofillers. It was reported that OP 1312 provided the best synergistic effect to NC, while CNF is compatible with OP $1230[108,109]$. A proportion of $20 \%$ OP was enough to achieve the $\mathrm{V}-0$ rating. In the same type of polyamide, but containing HNTs and OP1312, an improvement in mechanical, thermal and flame retarding 
properties has been observed by using a minimum concentration of $25 \% \mathrm{FR}$ and $2.5 \% \mathrm{NPs}$ [109].

By modifying the alkyl structure of the phosphinates, different fire retarding effects can be obtained on the polymer they are loaded in. Therefore, a novel salt of phosphinic acid was studied for enhancing the fire behaviour of many polymers. The aluminium salt of diisobutylphosphinic acid (ABPA) was synthesized to enhance the flame retardancy of PA6 composites. It works as a flame inhibitor in the gas phase during fire, having a minor effect in condensed phase. For PA6 combined with modified layered silicates like organo-modified montmorillonite (OMMT), the results showed an increase for the LOI of $21.0 \%$ for PA6/ OMMT6\% samples to $36.0 \%$ for PA6/OMMT2\%/ABPA $10 \%$ [110]. As for PA6/GF composites, the synergy between ABPA and monoisobutylphosphinic acid was demonstrated by the reduced pHRR $\left(288 \mathrm{~kW} / \mathrm{m}^{2}\right)$, increased LOI value (34.0\%) and V-0 classification in the UL-94 test [111].

Wang et al. [112] investigated the FR properties of an epoxy resin containing aluminium poly-hexamethylenephosphinate (APHP). The combustion analysis showed that APHP acted both in gas and condensed phaseby decreasing the PHRR, THR and EHC values. During combustion, APHP releases aluminium phosphate and alkylphosphinic structures, which lead to the formation of a reinforced insulation barrier by interacting with polymer fragments. In gaseous phase, the resultant $\mathrm{PO}$ and $\mathrm{PO}_{2}$ acted as fire inhibitors. It was found that $4 \mathrm{wt} \%$ APHP was sufficient to achieve a $\mathrm{V}-1$ rating in UL-94 test and a LOI value of $32.7 \%$.

Melamine was used in combinations with P-based compounds to obtain a synergistic effect that will increase the properties of the resultant additive. An example like melamine polyphosphate (MPP) was reported as an environmentally friendly flame retardant characterized by high thermal stability. In this compound the phosphate is an acid source while melamine acts as a blowing agent. During burning, the dehydrating action of the phosphate and the gases resulted by the degradation of the melamine influence the formation of the char layer.

As well as other melamine derivatives, MPP has been successfully used to limit the flammability of polyamides. Liu et al. [113] investigated the improvement of PA6 fire behaviour by adding MPP as flame retardant additive. PA6 was filled with silica fillers such as: fibrous wollastonite, talc and spherical glass bead. It was found that the geometric shape of the filler influenced the mechanical and combustion properties of PA6. Regarding UL-94 and LOI test, all three filled systems achieved a V-0 rating and LOI value $>33 \%$. Wollastonite had also a reinforcement effect both in polyamide and charred layer.

MPP can be used in synergistic combination with layered silicates as montmorillonite to increase the barrier properties of the char layer resulting in the intumescent process. It was shown that the co-addition of these compounds in PA6 increased the mechanical properties and improved the flame retardancy up to V-2 rating in UL-94 tests [114]. Regarding glass fibre reinforced PA66, MPP needed to be incorporated by approximately $25 \mathrm{wt} \%$ to obtain a positive effect on the fire behaviour: $38 \%$ LOI value and UL-94 V-0 classification [115].

The combination of several additives among them is a method to improve the fire behaviour of polymers. The resulting mixture exhibit a synergistic effect that increase

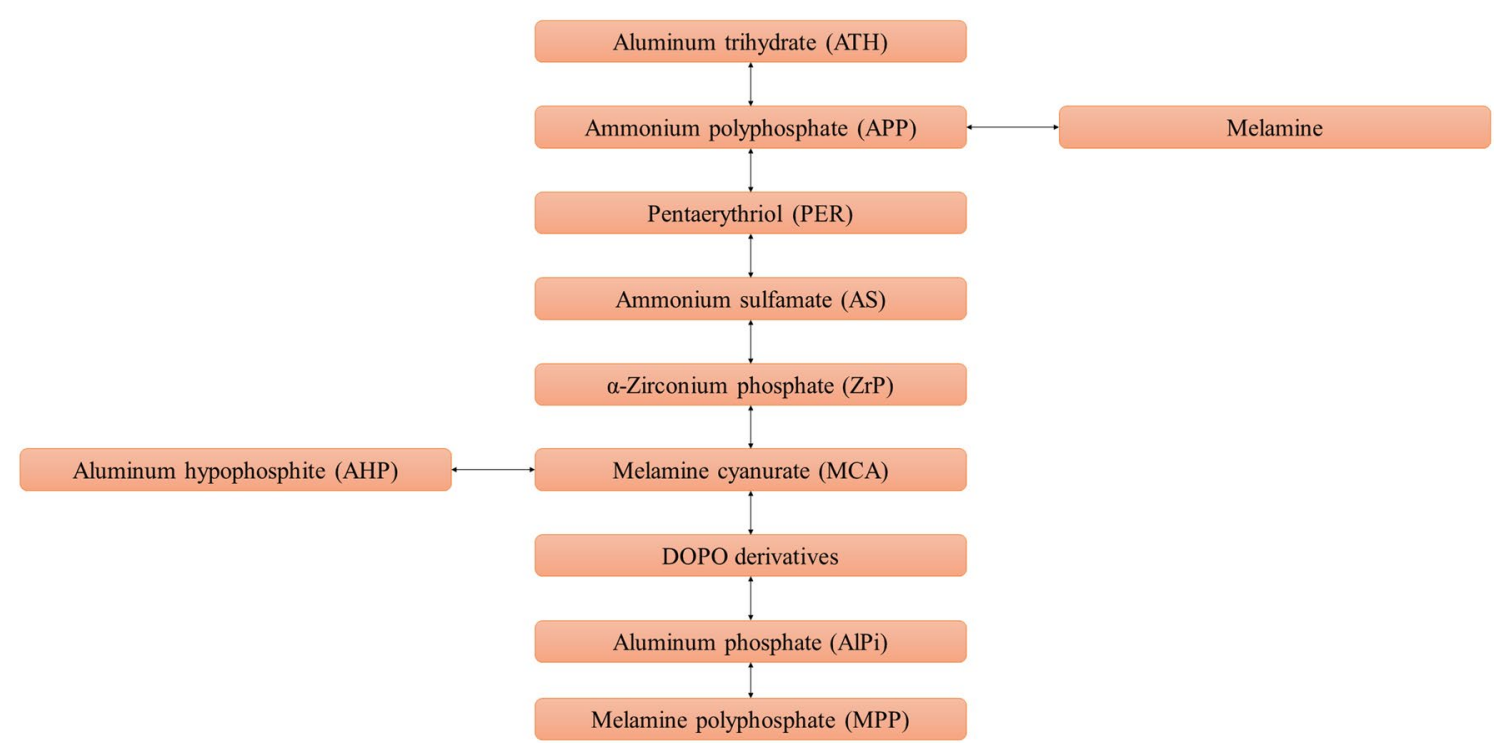

Fig. 7 Synergistic combinations of conventional FRs 
fire retardant properties. Figure 7 shows the possible synergistic combinations of the usual FRs reported in the literature. An example in this direction is MPP that acts as a synergist with aluminium phosphinate (AIPi). A protection mechanism of this mixture in PA6 was studied [116]. It was found that PA6/MPP-AIPi composites form during burning of a black charred bubble on the surface that acts as a gas filter. In this case, the main insulation is provided by the ceramic layer that appears under the bubble. The same type of layer was identified in samples of PA6/MPPAlPi with MMT content, but this time it showed a covering crust instead of the bubble. The crust acted as a gas barrier because of its composition: char, aluminophosphates, phosphinates and degraded polyamide. As for burning tests, cone calorimeter, LOI and UL-94 vertical tests were carried out. When $2 \%$ of the flame retardant mixture was replaced with OMMT, the samples showed the following performance: a V-0 classification in UL-94 tests, the LOI was increased to $32 \%$, while the pHRR was decreased by $75 \%$ [117].

Melamine poly(metalphosphate), under the commercial name Safire, belongs to a halogen-free flame retardant class which is considered an "enhanced version" of MPP. Melamine poly(zincphosphate) and its aluminium and magnesium analogues were studied as synergistic agents associated with AIPi in glass fibre-reinforced PA66. The mechanism of action in flame retardancy was reported by Naik et al. [118]. The authors disclosed the possible degradation pathway, relying on the chemical species they identified in both condensed and gas phases. A dosage of $15 \mathrm{wt} \%$ synergistic blends was sufficient to attain V-0 rating in UL-94 protocol and to enhance the cone calorimeter parameters: HRR and THR [119].

\section{Conclusions}

Flame retardants as seen for the last 10 years and as foreseen for the next future will still represent a very active topic. This was reflected by a large number of publications and correlated with the thermoplastic applications which will request in the near future even more intensive research. The flame retardants interaction with the environment was reported as the second most influential from all polymer additives after that of plasticizers. The presented data highlighted the alternatives to halogen $F R$, but with concrete application in an industrial perspective for a real replacement of some classical FR (with proven environmental and health severe problems).

The relationship between flame retardants and thermoplastics (especially with condensation polymer matrices, which are more prone to be degraded also in bio-processes) will evolve more and will ask for new solutions, more eco-friendly, less toxic in contact with humans, safer in critical condition (emissions of toxic gases during a fire situation).

Halogen-free flame retardants will remain a priority for the next few years at least. Halogen-based flame retardants are still very cost effective compared to the others. In industrial applications they will still exist as long as other robust solutions will not appear.

One of the most researched classes of halogen-free flame retardants consists in the phosphorous based agents. Among the organic flame retardants based on phosphorous, DOPO-derivatives play an important role. They are effective and versatile for the application in the polymer matrix; however, there are a lot of them already proven for their potential toxic risk.

Clay particles could play in the future a more important role, but more effective results are needed. In the same class, more advances are expected also for "greener" organo-modification agents available for clay.

Future perspectives of "greener" FR are tough and bright as well (like a craving "sunrise"). The tough perspective consists in two main problems: -classical FR solutions provide high performances compared with "green" FR (therefore for the new solution will be difficult to compete with, i.e. efficiency, costs); -some actual halogen free FR are not yet proven as dangerous as halogen ones.

Some of the "green" and very particular FR like nucleic acids (deoxyribonucleic acid) [120] were proven as interesting solutions for polyester fabrics, but their cost and production, makes them quite a mysterious route. However, the "sunrise" will come since large classes of proteins and amino acids were not intensively and in a sustainable manner researched. For examples some emerging direction based on phospho-proteins (like casein) could offer in the future some more realistic ways for animalsource bio-based FR [121]. However, few results were exploited in synthetic and bio-based condensation polymer thermoplastics.

Another hope for future directions is the combination of more accessible bio-based and biodegradable solutions with new classes of eco-friendly clay minerals. By this approach a potential cycle closing would be possible for the future fast bio-regenerating materials (with no waste on medium and long term). A potential future example of such smart bio-material, would be novel layered double hydroxides (LDH) for recovering phosphorous-based derivatives (from fresh waters areas i.e. affected by Eutrophication) and then used for FR applications (in new ecofriendly biodegradable materials) [122]. This potential FR class of modified LDH in polymer materials, when entering the end-of-life stage, can offer controlled release in soil to re-establish the environmental equilibrium [123]. We did 
not discuss LDH here since their power of action is driven also either by the metal hydroxyl content or by modifiers like phosphorous based compounds.

Some other examples for future FR, should not exclude classes like keratin, chitosan, new phosphor-based proteins or new classes of amino acids, modified clay particles with amino acids or amino acid sequences isolated from plants.

FR will play an important role in the future materials research,: the contact with materials, the consumption of materials and the environmental interface.

Acknowledgements This work was supported by a grant of the Romanian Ministry of Research and Innovation, CCCDI - UEFISCDI, project number PN-III-P1-1.2-PCCDI-2017-0387/80PCCDI Emerging technologies for the industrial application of 2D structures (graphene and non-graphene) Acronym EMERG2Ind, within PNCDIIII.

Funding This study was funded by $80 \mathrm{PCCDI} / 2018$

\section{Compliance with ethical standards}

Conflict of interest The authors declare that they have no conflict of interest.

\section{References}

1. Thakur S, Chaudhary J, Sharma B, Verma A, Tamulevicius S, Thakur VK (2018) Sustainability of bioplastics: opportunities and challenges. Curr Opin Green Sustain Chem 13:68-75. https ://doi.org/10.1016/j.cogsc.2018.04.013

2. Adu C, Jolly M, Thakur VK (2018) Exploring new horizons for paper recycling: a review of biomaterials and biorefinery feedstocks derived from wastepaper. Curr Opin Green Sustain Chem 13:21-26. https://doi.org/10.1016/j.cogsc.2018.03.003

3. Wróblewska-Krepsztul J, Rydzkowski T, Borowski G, Szczypiński M, Klepka T, Thakur VK (2018) Recent progress in biodegradable polymers and nanocomposite-based packaging materials for sustainable environment. Int J Polym Anal Charact 23(4):383395. https://doi.org/10.1080/1023666X.2018.1455382

4. Thakur VK, Thakur M, Gupta R (2014) Review: raw natural fiberbased polymer composites. Int J Polym Anal Charact 19:256271. https://doi.org/10.1080/1023666X.2014.880016

5. Babu RP, O'Connor K, Seeram R (2013) Current progress on biobased polymers and their future trends. Prog Biomater 2(1):8. https://doi.org/10.1186/2194-0517-2-8

6. Lambert S, Wagner M (2017) Environmental performance of bio-based and biodegradable plastics: the road ahead. Chem Soc Rev 46(22):6855-6871. https://doi.org/10.1039/C7CS0 0149E

7. Thakur S, Verma A, Sharma B, Chaudhary J, Tamulevicius S, Thakur VK (2018) Recent developments in recycling of polystyrene based plastics. Curr Opin Green Sustain Chem 13:32-38. https://doi.org/10.1016/j.cogsc.2018.03.011

8. Zhao H-B, Wang Y-Z (2017) Design and synthesis of PET-based copolyesters with flame-retardant and antidripping performance. Macromol Rapid Commun 38(23):1700451. https:// doi.org/10.1002/marc.201700451
9. Shao C-H, Wang T-Z, Chen G-N, Chen K-J, Yeh J-T, Chen K-N (2000) Aqueous-based polyurethane with dual-functional curing agent. J Polym Res 7(1):41-49. https://doi.org/10.1007/ s10965-006-0102-3

10. Yang W, Song L, Hu Y, Lu H, Yuen RKK (2011) Enhancement of fire retardancy performance of glass-fibre reinforced poly(ethylene terephthalate) composites with the incorporation of aluminum hypophosphite and melamine cyanurate. Compos Part B 42(5):1057-1065. https://doi.org/10.1016/j. compositesb.2011.03.019

11. Zhao X, Gao S, Liu G (2016) A THEIC-based polyphosphate melamine intumescent flame retardant and its flame retardancy properties for polylactide. J Anal Appl Pyrolysis 122:24-34. https://doi.org/10.1016/j.jaap.2016.10.029

12. Carosio F, Di Blasio A, Cuttica F, Alongi J, Frache A, Malucelli G (2013) Flame retardancy of polyester fabrics treated by sprayassisted layer-by-layer silica architectures. Ind Eng Chem Res 52(28):9544-9550. https://doi.org/10.1021/ie4011244

13. Zhu F, Feng QQ, Xu YF, Hu JF (2018) Intumescent flame retardant coating for polyamide 6,6 (PA 6,6) fabrics containing carbon nanotubes: synergistic effect of filler on thermal stability and flame retardancy. Text Res J 1:1. https://doi. org/10.1177/0040517518783355

14. Beard A, Angeler D (2010) Flame retardants: chemistry, applications, and environmental impacts. In: Lackner M, Winter F, Agarwal AK (eds) Handbook of combustion, vol 1. Wiley, New York. https://doi.org/10.1002/9783527628148.hoc017

15. Hahladakis JN, Velis CA, Weber R, lacovidou E, Purnell P (2018) An overview of chemical additives present in plastics: migration, release, fate and environmental impact during their use, disposal and recycling. J Hazard Mater 344:179-199. https:// doi.org/10.1016/j.jhazmat.2017.10.014

16. Bhunia K, Sablani SS, Tang J, Rasco B (2013) Migration of chemical compounds from packaging polymers during microwave, conventional heat treatment, and storage. Compr Rev Food Sci Food Saf 12(5):523-545. https://doi. org/10.1111/1541-4337.12028

17. Dris R, Imhof HK, Löder MGJ, Gasperi J, Laforsch C, Tassin B (2018) Chapter 3-microplastic contamination in freshwater systems: methodological challenges, occurrence and sources. In: Microplastic contamination in aquatic environments. Elsevier, pp. 51-93. https://doi.org/10.1016/B978-012-813747-5.00003-5

18. Anderson TZ, Cundy A, Croudace I, Warwick P, Celis-Hernandez O, Stead JL (2018) A rapid method for assessing the accumulation of microplastics in the sea surface microlayer (SML) of estuarine systems. Sci Rep. https://doi.org/10.1038/s4159 8-018-27612-w

19. Jang M, Shim WJ, Han GM, Rani M, Song YK, Hong SH (2017) Widespread detection of a brominated flame retardant, hexabromocyclododecane, in expanded polystyrene marine debris and microplastics from South Korea and the AsiaPacific coastal region. Environ Pollut 231:785-794. https:// doi.org/10.1016/j.envpol.2017.08.066

20. Sutton R, Chen D, Sun J, Greig DJ, Wu Y (2019) Characterization of brominated, chlorinated, and phosphate flame retardants in San Francisco Bay, an urban estuary. Sci Total Environ 652:212-223. https://doi.org/10.1016/j.scitotenv.2018.10.096

21. Shaw SD, Berger ML, Weijs L, Covaci A (2012) Tissue-specific accumulation of polybrominated diphenyl ethers (PBDEs) including Deca-BDE and hexabromocyclododecanes (HBCDs) in harbor seals from the northwest Atlantic. Environ Int 44:16. https://doi.org/10.1016/j.envint.2012.01.001

22. Kontrick AV (2018) Microplastics and human health: our great future to think about now. J Med Toxicol 14(2):117-119. https ://doi.org/10.1007/s13181-018-0661-9 
23. Smith M, Love DC, Rochman CM, Neff RA (2018) Microplastics in seafood and the implications for human health. Curr Environ Health Rep 5(3):375-386. https://doi.org/10.1007/s4057 2-018-0206-z

24. Van Cauwenberghe L, Janssen CR (2014) Microplastics in bivalves cultured for human consumption. Environ Pollut 193:65-70. https://doi.org/10.1016/j.envpol.2014.06.010

25. Wright S, Kelly JF (2017) Plastic and human health: A micro issue? Environ Sci Technol 51:6634-6647. https://doi. org/10.1021/acs.est.7b00423

26. Rabe S, Sanchez-Olivares G, Pérez-Chávez R, Schartel B (2019) Natural keratin and coconut fibres from industrial wastes in flame retarded thermoplastic starch biocomposites. Materials 12(3):344. https://doi.org/10.3390/ma12030344

27. Mariappan T, Wilkie CA (2014) Flame retardant epoxy resin for electrical and electronic applications. Fire Mater 38(5):588-598. https://doi.org/10.1002/fam.2199

28. Lyon R, Walters RN (2005) Flammability of automotive plastics. SAE [Tech Pap]. https://doi.org/10.4271/2006-01-1010

29. Qiu J, Yang T, Wang X, Wang L, Zhang G (2019) Review of the flame retardancy on highway tunnel asphalt pavement. Constr Build Mater 195:468-482. https://doi.org/10.1016/j.conbu ildmat.2018.11.034

30. Mattana G, Briand D, Marette A, Vásquez Quintero A, de Rooij NF (2015) Polylactic acid as a biodegradable material for allsolution-processed organic electronic devices. Org Electron 17:77-86. https://doi.org/10.1016/j.orgel.2014.11.010

31. Feng J, Ge Z, Chai C, Wang S, Yu D, Wu G, Luo Y (2016) Flame retardant modification of waterborne polyurethane fabric coating agent with high hydrostatic pressure resistance. Prog Org Coat 97:91-98. https://doi.org/10.1016/j.porgcoat.2016.03.020

32. Zhang P, Fan H, Hu K, Gu Y, Chen Y, Yan J, Tian S, He Y (2018) Solvent-free two-component polyurethane conjugated with crosslinkable hydroxyl-functionalized ammonium polyphosphate: curing behaviors, flammability and mechanical properties. Prog Org Coat 120:88-99. https://doi.org/10.1016/j.porgc oat.2018.01.019

33. Zhang $\mathrm{H}$, Wang $\mathrm{H}$, Wang $\mathrm{H}$ (2018) Flame retardant mechanism and surface modification of magnesium hydroxide flame retardant. Paper presented at the IOP conf. series: earth and environmental science

34. Hennessey BC (2017) Test procedures for evaluating flammability of interior materials. SAE Government Industry Meeting. https://www.nhtsa.gov/sites/nhtsa.dot.gov/files/docum ents/2017saebhennessey.pdf. Accessed 23 Jan 2019

35. DIN 4102-1 (1998) Fire behaviour of building materials and elements

36. ISO 4589 (2017) Determination of burning behaviour by oxygen index

37. Liu K, Li Y, Tao L, Xiao R (2018) Preparation and characterization of polyamide 6 fibre based on a phosphorus-containing flame retardant. RSC Adv 8(17):9261-9271. https://doi.org/10.1039/ C7RA13228J

38. Yang X, Li Q, Chen Z, Han H (2009) Fabrication and thermal stability studies of polyamide 66 containing triaryl phosphine oxide. Bull Mater Sci 32(4):375. https://doi.org/10.1007/s1203 4-009-0054-4

39. Baltaci B, Çakal G, Bayram G, Eroglu I, Özkar S (2015) Surfactant modified zinc borate synthesis and its effect on the properties of PET. Powder Technol 244:38-44. https://doi.org/10.1016/j. powtec.2013.04.006

40. Shi X, Jiang S, Zhu J, Li G, Peng X (2018) Establishment of a highly efficient flame-retardant system for rigid polyurethane foams based on bi-phase flame-retardant actions. RSC Adv 8(18):9985-9995. https://doi.org/10.1039/C7RA13315D
41. Yu S, Xiang H, Zhou J, Zhu M (2018) Enhanced flame-retardant performance of poly (lactic acid) (PLA) composite by using intrinsically phosphorus-containing PLA. Prog Nat Sci Mater Int 28(5):590-597. https://doi.org/10.1016/j.pnsc.2018.09.002

42. Lindholm J, Brink A, Hupa M (2009) Cone calorimeter-a tool for measuring heat release rate. Paper presented at the FinnishSwedish Flame Days 2009, Åbo Akademi Process Chemistry Centre, Finland

43. Wang $Y$, Wang $F$, Dong $Q$, Xie M, Liu P, Ding Y, Zhang S, Yang M, Zheng G (2017) Core-shell expandable graphite @ aluminum hydroxide as a flame-retardant for rigid polyurethane foams. Polym Degrad Stab 146:267-276. https://doi.org/10.1016/j. polymdegradstab.2017.10.017

44. Khalili P, Tshai KY, Hui D, Kong I (2017) Synergistic of ammonium polyphosphate and alumina trihydrate as fire retardants for natural fiber reinforced epoxy composite. Compos Part B 114:101-110. https://doi.org/10.1016/j.composites b.2017.01.049

45. Hapuarachchi DT (2009) Aluminium trihydroxide in combination with ammonium polyphosphate as flame retardants for unsaturated polyester resin. eXPRESS Polym Lett 3:743-751. https://doi.org/10.3144/expresspolymlett.2009.92

46. Liu Y, He J, Yang R (2015) The effects of aluminum hydroxide and ammonium polyphosphate on the flame retardancy and mechanical property of polyisocyanuratepolyurethane foams. J Fire Sci 33(6):459-472. https://doi. org/10.1177/0734904115609362

47. Yunshu Z, Yuan Y, Qingwu Z (2018) Effects of dimethyl methylphosphonate, aluminum hydroxide and ammonium polyphosphate on the flame retardancy and thermal properties of unsaturated polyester resin. IOP Conf Ser Mater Sci Eng 394(2):022029

48. Kozlowski R, Wladyka-Przybylak M, Garbarczyk J (2000) The flame retardant for polypropylene using magnesium hydroxide with intumescent components. Mol Cryst Liq Cryst Sci Technol, Sect A 354(1):195-206. https://doi. org/10.1080/10587250008023614

49. Hornsby PR, Wang J, Rothon R, Jackson G, Wilkinson G, Cossick K (1996) Thermal decomposition behavior of polyamide fire-retardant compositions containing magnesium hydroxide filler. Polym Degrad Stab 51:235-249. https://doi. org/10.1016/0141-3910(95)00181-6

50. Przepiórski J, Karolczyk J, Tsumura T, Toyoda M, Inagaki M, Morawski AW (2012) Effect of some thermally unstable magnesium compounds on the yield of char formed from poly(ethylene terephthalate). J Therm Anal Calorim 107(3):1147-1154. https://doi.org/10.1007/s1097 3-011-1910-1

51. Hornsby PR, Wang J, Rothon R, Jackson G, Wilkinson G, Cossick K (1996) Thermal decomposition behaviour of polyamide fire-retardant compositions containing magnesium hydroxide filler. Polym Degrad Stab 51(3):235-249. https://doi. org/10.1016/0141-3910(95)00181-6

52. Balakrishnan $H$, Hassan A, Isitman NA, Kaynak C (2012) On the use of magnesium hydroxide towards halogen-free flameretarded polyamide-6/polypropylene blends. Polym Degrad Stab 97(8):1447-1457. https://doi.org/10.1016/j.polymdegra dstab.2012.05.011

53. Yang Y, Niu M, Li J, Xue B, Dai J (2016) Preparation of carbon microspheres coated magnesium hydroxide and its application in polyethylene terephthalate as flame retardant. Polym Degrad Stab 134:1-9. https://doi.org/10.1016/j.polymdegra dstab.2016.09.019

54. Tang H, X-b Zhou, X-I Liu (2013) Effect of magnesium hydroxide on the flame retardant properties of unsaturated polyester 
resin. Procedia Eng 52:336-341. https://doi.org/10.1016/j. proeng.2013.02.150

55. Saxena V, Diaz A, Clearfield A, Batteas J, Hussain M (2013) Zirconium phosphate nanoplatelets: a biocompatible nanomaterial for drug delivery to cancer. Nanoscale 5:1. https://doi. org/10.1039/c3nr34242e

56. Kalita H, Kumar BP, Konar S, Tantubay S, Mahto MK, Mandal M, Pathak A (2016) Sonochemically synthesized biocompatible zirconium phosphate nanoparticles for $\mathrm{pH}$ sensitive drug delivery application. Mater Sci Eng 60:84-91. https:// doi.org/10.1016/j.msec.2015.11.010

57. Kullberg L, Clearfield A (1981) Mechanism of ion exchange in zirconium phosphates. 32. Thermodynamics of alkali metal ion exchange on crystalline.alpha.-zirconium phosphate. J Phys Chem 85(11):1585-1589. https://doi.org/10.1021/j1506 $11 \mathrm{a} 025$

58. Bae JW, Park S-J, Woo MH, Cheon JY, Ha K-S, Jun K-W, Lee D-H, Jung HM (2011) Enhanced catalytic performance by zirconium phosphate-modified $\mathrm{SiO}_{2}$-supported $\mathrm{Ru}$-Co catalyst for Fischer-Tropsch synthesis. ChemCatChem 3(8):1342-1347. https ://doi.org/10.1002/cctc.201100102

59. Rosenthal GL, Caruso J (1991) Photochemical behavior of metal complexes intercalated in zirconium phosphate. J Solid State Chem 93(1):128-133. https://doi.org/10.1016/00224596(91)90281-L

60. Huang T-C, Lai G-H, Li C-E, Tsai M-H, Wan P-Y, Chung Y-H, Lin $\mathrm{M}-\mathrm{H}$ (2017) Advanced anti-corrosion coatings prepared from a-zirconium phosphate/polyurethane nanocomposites. RSC Adv 7:9908-9913. https://doi.org/10.1039/C6RA27588E

61. Alongi J, Frache A (2010) Flame retardancy properties of a-zirconium phosphate based composites. Polym Degrad Stab 95(9):1928-1933. https://doi.org/10.1016/j.polymdegradstab .2010 .04 .007

62. Xiang H, Li L, Chen W, Yu S, Sun B, Zhu M (2017) Flame retardancy of polyamide 6 hybrid fibers: combined effects of a-zirconium phosphate and ammonium sulfamate. Prog Nat Sci Mater Int 27(3):369-373. https://doi.org/10.1016/j. pnsc.2017.04.013

63. Xiao Y, Xu J, Huang S, Deng H (2017) Effects of a-ZrP on crystallinity and flame-retardant behaviors of PA6/MCA composites. Int J Polym Sci 2017:12. https://doi.org/10.1155/2017/6034741

64. Liu X-Q, Wang D-Y, Wang X-L, Chen L, Wang Y-Z (2011) Synthesis of organo-modified a-zirconium phosphate and its effect on the flame retardancy of IFR poly(lactic acid) systems. Polym Degrad Stab 96:771-777. https://doi.org/10.1016/j.polymdegra dstab.2011.02.022

65. Liu X-Q, Wang D-Y, Wang X-L, Chen L, Wang Y-Z (2013) Synthesis of functionalized a-zirconium phosphate modified with intumescent flame retardant and its application in poly(lactic acid). Polym Degrad Stab 98:1731-1737. https://doi.org/10.1016/j. polymdegradstab.2013.06.001

66. Yu S, Xiang H, Zhou J, Zhou Z, Zhu M (2018) The synergistic effect of organic phosphorous/a-zirconium phosphate on flame-retardant poly(lactic acid) fiber. Fibers Polym 19(4):812820. https://doi.org/10.1007/s12221-018-7828-5

67. Zhao B, Hu Z, Chen L, Liu Y, Liu Y, Wang Y-Z (2011) A phosphorus-containing inorganic compound as an effective flame retardant for glass-fiber-reinforced polyamide 6. J Appl Polym Sci 119(4):2379-2385. https://doi.org/10.1002/app.32860

68. Li Q, Li B, Zhang S, Lin M (2012) Investigation on effects of aluminum and magnesium hypophosphites on flame retardancy and thermal degradation of polyamide 6. J Appl Polym Sci 125(3):1782-1789. https://doi.org/10.1002/app.35678

69. Ge H, Tang G, Hu WZ, Wang BB, Pan Y, Song L, Hu Y (2015) Aluminum hypophosphite microencapsulated to improve its safety and application to flame retardant polyamide $6 . \mathrm{J}$
Hazard Mater 294:186-194. https://doi.org/10.1016/j.jhazm at.2015.04.002

70. Wang G, Wang Y, Yang J (2012) Influences of polymerization degree of ammonium polyphosphate on fire protection of waterborne intumescent fire resistive coating. Surf Coat Technol 206(8):2275-2280. https://doi.org/10.1016/j.surfc oat.2011.10.003

71. Sun L, Qu Y, Li S (2013) Co-microencapsulate of ammonium polyphosphate and pentaerythritol in intumescent flameretardant coatings. J Therm Anal Calorim 111(2):1099-1106. https://doi.org/10.1007/s10973-012-2494-0

72. Tarakcilar AR (2011) The effects of intumescent flame retardant including ammonium polyphosphate/pentaerythritol and fly ash fillers on the physicomechanical properties of rigid polyurethane foams. J Appl Polym Sci 120(4):2095-2102. https://doi. org/10.1002/app.33377

73. Chiu S-H, Wang W-K (1998) Dynamic flame retardancy of polypropylene filled with ammonium polyphosphate, pentaerythritol and melamine additives. Polymer 39(10):1951-1955. https ://doi.org/10.1016/S0032-3861(97)00492-8

74. Dahiya JB, Rathi S, Bockhorn H, Haußmann M, Kandola BK (2012) The combined effect of organic phoshphinate/ammonium polyphosphate and pentaerythritol on thermal and fire properties of polyamide 6-clay nanocomposites. Polym Degrad Stab 97(8):1458-1465. https://doi.org/10.1016/j.polymdegra dstab.2012.05.012

75. Battegazzore D, Alongi J, Fontaine G, Frache A, Bourbigot S, Malucelli G (2015) Bulk vs. surface flame retardancy of fully biobased polyamide 10,10. RSC Adv 5(49):39424-39432. https:// doi.org/10.1039/C5RA04149J

76. Li L, Chen G, Liu W, Li J, Zhang S (2009) The anti-dripping intumescent flame retardant finishing for nylon-6,6 fabric. Polym Degrad Stab 94(6):996-1000. https://doi.org/10.1016/j.polym degradstab.2009.02.009

77. Patrick Lim WK, Mariatti M, Chow WS, Mar KT (2012) Effect of intumescent ammonium polyphosphate (APP) and melamine cyanurate (MC) on the properties of epoxy/glass fiber composites. Compos Part B 43(2):124-128. https://doi.org/10.1016/j. compositesb.2011.11.013

78. Shen M-Y, Chen W-J, Kuan C-F, Kuan H-C, Yang J-M, Chiang C-L (2016) Preparation, characterization of microencapsulated ammonium polyphosphate and its flame retardancy in polyurethane composites. Mater Chem Phys 173:205-212. https:// doi.org/10.1016/j.matchemphys.2016.02.006

79. Wang X, Hu Y, Song L, Xuan S, Xing W, Bai Z, Lu H (2011) Flame retardancy and thermal degradation of intumescent flame retardant poly(lactic acid)/starch biocomposites. Ind Eng Chem Res 50(2):713-720. https://doi.org/10.1021/ie1017157

80. Hu W, Wang B, Wang X, Ge H, Song L, Wang J, Hu Y (2014) Effect of ethyl cellulose microencapsulated ammonium polyphosphate on flame retardancy, mechanical and thermal properties of flame retardant poly(butylene succinate) composites. J Therm Anal Calorim 117(1):27-38. https://doi.org/10.1007/ s10973-014-3680-z

81. Lu X, Qiao X, Yang T, Sun K, Chen X (2011) Preparation and properties of environmental friendly nonhalogen flame retardant melamine cyanurate/nylon 66 composites. J Appl Polym Sci 122(3):1688-1697. https://doi.org/10.1002/app.34035

82. Tamura K, Ohyama S, Umeyama K, Kitazawa T, Yamagishi A (2016) Preparation and properties of halogen-free flameretardant layered silicate-polyamide 66 nanocomposites. Appl Clay Sci 126:107-112. https://doi.org/10.1016/j. clay.2016.02.027

83. Šehić A, Vasiljević J, Demšar A, Leskovšek $M$, Bukošek $V$, Medved J, Čolović M, Jerman I, Simončič B (2019) Polyamide 6 composite fibers with incorporated mixtures of melamine 
cyanurate, carbon nanotubes, and carbon black. J Appl Polym Sci 136(5):47007. https://doi.org/10.1002/app.47007

84. Tang S, Qian L-J, Qiu Y, Sun N (2014) The effect of morphology on the flame-retardant behaviors of melamine cyanurate in PA6 composites. J Appl Polym Sci. https://doi.org/10.1002/ app.40558

85. Tao W, Li J (2018) Melamine cyanurate tailored by base and its multi effects on flame retardancy of polyamide 6. Appl Surf Sci 456:751-762. https://doi.org/10.1016/j.apsusc.2018.06.215

86. Lehrle RS, Parsons IW, Rollinson M (2000) Thermal degradation mechanisms of nylon 6 deduced from kinetic studies by pyrolysis-g.c. Polym Degrad Stab 67(1):21-33. https://doi. org/10.1016/S0141-3910(99)00112-3

87. Achhammer BG, Reinhart FW, Kline GM (1951) Mechanism of the degradation of polyamides. J Appl Chem 1(7):301-320. https://doi.org/10.1002/jctb.5010010704

88. Gonçalves ES, Poulsen L, Ogilby PR (2007) Mechanism of the temperature-dependent degradation of polyamide 66 films exposed to water. Polym Degrad Stab 92(11):1977-1985. https://doi.org/10.1016/j.polymdegradstab.2007.08.007

89. Liu Y, Wang Q (2009) The investigation on the flame retardancy mechanism of nitrogen flame retardant melamine cyanurate in polyamide 6. J Polym Res 16(5):583-589. https ://doi.org/10.1007/s10965-008-9263-6

90. Thirumal M, Khastgir D, Nando GB, Naik YP, Singha NK (2010) Halogen-free flame retardant PUF: effect of melamine compounds on mechanical, thermal and flame retardant properties. Polym Degrad Stab 95(6):1138-1145. https://doi. org/10.1016/j.polymdegradstab.2010.01.035

91. Rao W-H, Hu Z-Y, Xu H-X, Xu Y-J, Qi M, Liao W, Xu S, Wang Y-Z (2017) Flame-retardant flexible polyurethane foams with highly efficient melamine salt. Ind Eng Chem Res 56(25):7112-7119. https://doi.org/10.1021/acs.iecr.7b01335

92. Schäfer A, Seibold S, Lohstroh W, Walter O, Döring M (2007) Synthesis and properties of flame-retardant epoxy resins based on DOPO and one of its analog DPPO. J Appl Polym Sci 105:685-696. https://doi.org/10.1002/app.26073

93. Hu J, Shan J, Wen D, Liu X, Zhao J, Tong Z (2014) Flame retardant, mechanical properties and curing kinetics of DOPObased epoxy resins. Polym Degrad Stab 109:218-225. https ://doi.org/10.1016/j.polymdegradstab.2014.07.026

94. Wang T, Wang J, Huo S, Zhang B, Yang S (2016) Preparation and flame retardancy of DOPO-based epoxy resin containing bismaleimide. High Perform Polym 28(9):1090-1095. https:// doi.org/10.1177/0954008316631591

95. Zhang Y, Yu B, Wang B, Liew K, Song L, Wang C, Hu Y (2017) Highly effective P-P synergy of a novel DOPO-based flame retardant for epoxy resin. Ind Eng Chem Res 56:1245-1255. https://doi.org/10.1021/acs.iecr.6b04292

96. König A, Kroke E (2011) Methyl-DOPO_-a new flame retardant for flexible polyurethane foam. Polym Adv Technol 22(1):5-13. https://doi.org/10.1002/pat.1728

97. Li YY, Liu K, Xiao R (2017) Preparation and characterizations of flame retardant polyamide 66 fiber. IOP Conf Ser Mater Sci Eng 213(1):012040

98. Cao Y, Wang X-L, Zhang W-Q, Yin X-W, Shi Y-Q, Wang Y-Z (2017) $\mathrm{Bi}-\mathrm{DOPO}$ structure flame retardants with or without reactive group: their effects on thermal stability and flammability of unsaturated polyester. Ind Eng Chem Res 56(20):5913-5924. https://doi.org/10.1021/acs.iecr.7b00711

99. Salmeia K, Gooneie A, Simonetti P, Nazir R, Kaiser J-P, Rippl A, Hirsch C, Lehner S, Rupper P, Hufenus R, Gaan S (2018) Comprehensive study on flame retardant polyesters from phosphorus additives. Polym Degrad Stab 155:22-34. https ://doi.org/10.1016/j.polymdegradstab.2018.07.006
100. Schartel B, Balabanovich Al, Braun U, Knoll U, Artner J, Ciesielski M, Döring M, Perez R, Sandler JKW, Altstädt V, Hoffmann T, Pospiech D (2007) Pyrolysis of epoxy resins and fire behavior of epoxy resin composites flame-retarded with 9,10-dihydro-9-oxa-10-phosphaphenanthrene-10-oxide additives. J Appl Polym Sci 104(4):2260-2269. https://doi.org/10.1002/ app. 25660

101. Buczko A, Stelzig T, Bommer L, Rentsch D, Heneczkowski M, Gaan S (2014) Bridged DOPO derivatives as flame retardants for PA6. Polym Degrad Stab 107:158-165. https://doi. org/10.1016/j.polymdegradstab.2014.05.017

102. Huang W, He W, Long L, Yan W, He M, Qin S, Yu J (2018) Highly efficient flame-retardant glass-fiber-reinforced polyamide $6 \mathrm{~T}$ system based on a novel DOPO-based derivative: flame retardancy, thermal decomposition, and pyrolysis behavior. Polym Degrad Stab 148:26-41. https://doi.org/10.1016/j.polymdegra dstab.2018.01.008

103. Li M, Zhong $Y$, Wang Z, Fischer A, Ranft F, Drummer D, Wu W (2016) Flame retarding mechanism of Polyamide 6 with phosphorus-nitrogen flame retardant and DOPO derivatives. J Appl Polym Sci. https://doi.org/10.1002/app.42932

104. Sahyoun J, Bounor-Legaré V, Ferry L, Sonnier R, Da Cruz-Boisson F, Melis F, Bonhommé A, Cassagnau P (2015) Synthesis of a new organophosphorous alkoxysilane precursor and its effect on the thermal and fire behavior of a PA66/PA6 copolymer. Eur Polym J 66:352-366. https://doi.org/10.1016/j.eurpo lymj.2015.02.036

105. Cai J, Wirasaputra A, Zhu Y, Liu S, Zhou Y, Zhang C, Zhao J (2017) The flame retardancy and rheological properties of PA6/MCA modified by DOPO-based chain extender. RSC Adv 7(32):19593-19603. https://doi.org/10.1039/C6RA28293H

106. Lorenzetti A, Besco S, Hrelja D, Roso M, Gallo E, Schartel B, Modesti M (2013) Phosphinates and layered silicates in charring polymers: the flame retardancy action in polyurethane foams. Polym Degrad Stab 98(11):2366-2374. https://doi. org/10.1016/j.polymdegradstab.2013.08.002

107. Batistella MA, Sonnier R, Otazaghine B, Petter CO, Lopez-Cuesta JM (2018) Interactions between kaolinite and phosphinatebased flame retardant in Polyamide 6. Appl Clay Sci 157:248256. https://doi.org/10.1016/j.clay.2018.02.02

108. Lao SC, Koo JH, Moon TJ, Londa M, Ibeh CC, Wissler GE, Pilato LA (2011) Flame-retardant polyamide 11 nanocomposites: further thermal and flammability studies. J Fire Sci 29(6):479-498. https://doi.org/10.1177/0734904111404658

109. Hao A, Wong I, Wu H, Lisco B, Ong B, Sallean A, Butler S, Londa $M$, Koo JH (2015) Mechanical, thermal, and flame-retardant performance of polyamide 11-halloysite nanotube nanocomposites. J Mater Sci 50(1):157-167. https://doi.org/10.1007/s1085 3-014-8575-7

110. He W, Zhu H, Xiang Y, Long L, Qin S, Yu J (2017) Enhancement of flame retardancy and mechanical properties of polyamide 6 by incorporating an aluminum salt of diisobutylphosphinic combined with organoclay. Polym Degrad Stab 144:442-453. https://doi.org/10.1016/j.polymdegradstab.2017.09.003

111. Hu Z, Chen L, Lin G-P, Luo Y, Wang Y-Z (2011) Flame retardation of glass-fibre-reinforced polyamide 6 by a novel metal salt of alkylphosphinic acid. Polym Degrad Stab 96(9):1538-1545. https://doi.org/10.1016/j.polymdegradstab.2011.03.010

112. Wang J, Qian L, Xu B, Xi W, Liu X (2015) Synthesis and characterization of aluminum poly-hexamethylenephosphinate and its flame-retardant application in epoxy resin. Polym Degrad Stab 122:8-17. https://doi.org/10.1016/j.polymdegradstab .2015 .10 .011

113. Liu Y, Li J, Wang Q (2009) The investigation of melamine polyphosphate flame retardant polyamide-6/inorganic 
siliciferous filler with different geometrical form. J Appl Polym Sci 113(3):2046-2051. https://doi.org/10.1002/app.30035

114. Kiliaris P, Papaspyrides CD, Xalter R, Pfaendner R (2012) Study on the properties of polyamide 6 blended with melamine polyphosphate and layered silicates. Polym Degrad Stab 97(7):1215-1222. https://doi.org/10.1016/j.polymdegradstab .2012 .03 .005

115. Fu X, Liu Y, Wang Q, Zhang Z, Wang Z, Zhang J (2011) Novel synthesis method for melamine polyphosphate and its flame retardancy on glass fiber reinforced polyamide 66 . Polym Plast Technol Eng 50(15):1527-1532. https://doi.org/10.1080/03602 559.2011 .603777

116. Samyn F, Bourbigot S (2014) Protection mechanism of a flameretarded polyamide 6 nanocomposite. J Fire Sci 32(3):241-256. https://doi.org/10.1177/0734904113510685

117. Bourbigot S, Duquesne S, Fontaine G, Bellayer S, TurfT, Samyn $F$ (2008) Characterization and reaction to fire of polymer nanocomposites with and without conventional flame retardants. Mol Cryst Liq Cryst 486(1):325/[1367]-1339/[1381]. https://doi. org/10.1080/15421400801921983

118. Naik AD, Fontaine $G$, Samyn F, Delva X, Louisy J, Bellayer S, Bourgeois Y, Bourbigot $S$ (2014) Outlining the mechanism of flame retardancy in polyamide 66 blended with melamine-poly(zinc phosphate). Fire Saf J 70:46-60. https://doi.org/10.1016/j.fires af.2014.08.019

119. Naik AD, Fontaine $G$, Samyn F, Delva $X$, Bourgeois $Y$, Bourbigot $S$ (2013) Melamine integrated metal phosphates as non-halogenated flame retardants: synergism with aluminium phosphinate for flame retardancy in glass fiber reinforced polyamide 66. Polym Degrad Stab 98(12):2653-2662. https://doi. org/10.1016/j.polymdegradstab.2013.09.029

120. Malucelli G, Bosco F, Alongi J, Carosio F, Di Blasio A, Mollea C, Cuttica F, Casale A (2014) Biomacromolecules as novel green flame retardant systems for textiles: an overview. RSC Adv 4(86):46024-46039. https://doi.org/10.1039/C4RA06771A

121. Alongi J, Carletto RA, Bosco F, Carosio F, Di Blasio A, Cuttica F, Antonucci V, Giordano M, Malucelli G (2014) Caseins and hydrophobins as novel green flame retardants for cotton fabrics. Polym Degrad Stab 99:111-117. https://doi.org/10.1016/j. polymdegradstab.2013.11.016

122. Yan H, Chen Q, Liu J, Feng Y, Shih K (2018) Phosphorus recovery through adsorption by layered double hydroxide nanocomposites and transfer into a struvite-like fertilizer. Water Res 145:721-730. https://doi.org/10.1016/j.watres.2018.09.005

123. Bernardo MP, Guimarães GGF, Majaron VF, Ribeiro C (2018) Controlled release of phosphate from layered double hydroxide structures: dynamics in soil and application as smart fertilizer. ACS Sustain Chem Eng 6(4):5152-5161. https://doi. org/10.1021/acssuschemeng.7b04806

Publisher's Note Springer Nature remains neutral with regard to jurisdictional claims in published maps and institutional affiliations. 